\title{
Monitoring Grassland Seasonal Carbon Dynamics, by Integrating MODIS NDVI, Proximal Optical Sampling, and Eddy Covariance Measurements
}

\author{
Enrica Nestola ${ }^{1, *}$, Carlo Calfapietra ${ }^{1,2}$, Craig A. Emmerton ${ }^{3}$, Christopher Y.S. Wong ${ }^{4}$, \\ Donnette R. Thayer ${ }^{5}$ and John A. Gamon ${ }^{3, *}$ \\ 1 Institute of Agro-Environmental \& Forest Biology (IBAF), National Research Council (CNR), Via Marconi 2, \\ Porano (TR) 05010, Italy; carlo.calfapietra@ibaf.cnr.it \\ 2 Czechglobe, Global Change Research Centre, Bělidla 986/4a, 60300 Brno, Czech Republic \\ 3 Departments of Earth and Atmospheric Sciences and Biological Sciences, University of Alberta, \\ Edmonton, AB T6G 2E3, Canada; emmerton@ualberta.ca \\ 4 Department of Biology, University of Toronto Mississauga, Mississauga, ON L5L 1C6, Canada; \\ cyet.wong@mail.utoronto.ca \\ 5 Department of Renewable Resources, University of Alberta, Edmonton, AB T6G 2E3, Canada; \\ thayer@ualberta.ca \\ * Correspondence: enrica.nestola@ibaf.cnr.it (E.N.); jgamon@gmail.com (J.A.G.); Tel.: +39-076-337-4943 (E.N.); \\ +1-780-492-0345 (J.A.G.)
}

Academic Editors: Sangram Ganguly, Compton Tucker, Parth Sarathi Roy and Prasad S. Thenkabail Received: 8 January 2016; Accepted: 14 March 2016; Published: 19 March 2016

\begin{abstract}
This study evaluated the seasonal productivity of a prairie grassland (Mattheis Ranch, in Alberta, Canada) using a combination of remote sensing, eddy covariance, and field sampling collected in 2012-2013. A primary objective was to evaluate different ways of parameterizing the light-use efficiency (LUE) model for assessing net ecosystem fluxes at two sites with contrasting productivity. Three variations on the NDVI (Normalized Difference Vegetation Index), differing by formula and footprint, were derived: (1) a narrow-band NDVI (NDVI 680,800 , derived from mobile field spectrometer readings); (2) a broad-band proxy NDVI (derived from an automated optical phenology station consisting of broad-band radiometers); and (3) a satellite NDVI (derived from MODIS AQUA and TERRA sensors). Harvested biomass, net $\mathrm{CO}_{2}$ flux, and NDVI values were compared to provide a basis for assessing seasonal ecosystem productivity and gap filling of tower flux data. All three NDVIs provided good estimates of dry green biomass and were able to clearly show seasonal changes in vegetation growth and senescence, confirming their utility as metrics of productivity. When relating fluxes and optical measurements, temporal aggregation periods were considered to determine the impact of aggregation on model accuracy. NDVI values from the different methods were also calibrated against $f$ APAR $_{\text {green }}$ (the fraction of photosynthetically active radiation absorbed by green vegetation) values to parameterize the APAR green (absorbed PAR) term of the LUE (light use efficiency) model for comparison with measured fluxes. While efficiency was assumed to be constant in the model, this analysis revealed hysteresis in the seasonal relationships between fluxes and optical measurements, suggesting a slight change in efficiency between the first and second half of the growing season. Consequently, the best results were obtained by splitting the data into two stages, a greening phase and a senescence phase, and applying separate fits to these two periods. By incorporating the dynamic irradiance regime, the model based on APAR green rather than NDVI best captured the high variability of the fluxes and provided a more realistic depiction of missing fluxes. The strong correlations between these optical measurements and independently measured fluxes demonstrate the utility of integrating optical with flux measurements for gap filling, and provide a foundation for using remote sensing to extrapolate from the flux tower to larger regions (upscaling) for regional analysis of net carbon uptake by grassland ecosystems.
\end{abstract}

Keywords: grassland; NDVI; $\mathrm{CO}_{2}$ flux; optical remote sensing; LUE model; gap filling 


\section{Introduction}

The need to better understand and predict future carbon-climate interactions makes the assessment of biosphere-atmosphere carbon exchange for the various biomes of the planet a critical topic for the scientific community and policy-makers [1]. There is growing interest in assessing biospheric carbon storage with the hope that management regimes can optimize carbon sequestration. Also, soil processes play an important role in global climate change as soils have the potential to act as a net sink for $\mathrm{CO}_{2}$ due to the large amount of carbon currently stored in soil organic matter [2,3]. However, biosphere-atmosphere carbon fluxes are inherently dynamic, affected by short-term disturbance and weather events, making evaluation and prediction of carbon storage and climate feedbacks challenging. While much attention has been given to forests for their large feedback and carbon sequestration [4], the carbon storage potential of other biomes has been less thoroughly considered, even though many non-forest biomes cover large areas, contribute measurably to overall biospheric carbon uptake and storage, and provide economically important ecosystem goods and services.

Rangelands occupy close to 50\% of the world's land area [5]. They are defined as lands where indigenous or introduced vegetation is grazed or has the potential to be grazed and are generally considered and managed as natural ecosystems [6]. Rangelands include natural grasslands, savannas, shrublands, deserts, tundra, alpine communities, marshes, and wet meadows [7]. The grassland or prairie biome is particularly important in Alberta, as the Grassland Natural Region covers $14.4 \%$ of the province [8]. The Dry Mixedgrass Natural Subregion accounts for $47.5 \%$ of the Grassland Natural Region area, and thus represents $7 \%$ of the area of Alberta province [9]. Grassland provides a number of important services including carbon sequestration and livestock forage. The capacity of grassland ecosystems to sequester carbon is a leading factor in the consideration of policies and practices that maximize carbon storage without compromising managers' profits [10]. The carbon sequestration of a grassland can vary considerably from year to year since it is influenced both by natural and anthropogenic factors such as temperature, rainfall, species composition, nutrient and water availability, light, grazing pressure and agricultural practices [11,12]. Together, these factors make grassland carbon exchange responsive to climate change [13-15], and drive interest in monitoring grassland ecosystem responses for the purpose of developing optimal management regimes.

Historically, most attempts to assess ecosystem carbon storage have been based on field sampling of above- and below-ground biomass and carbon, which requires considerable investments in time and personnel [16], and may not capture the temporal dynamics in response to changing conditions. Ecosystem carbon dynamics have been modeled using different input parameters including climate $[17,18]$ or soil and nutrient availability $[19,20]$. However, models often lack spatially or temporally sufficient data inputs, so may not take into account all ecosystem dynamics and interactions.

Significant progress in understanding ecosystem dynamics has been accomplished using the eddy covariance (EC) technique, which quantifies carbon and water vapor fluxes between the biosphere and the atmosphere [21]. This technique has been successfully applied to estimate carbon fluxes in grassland ecosystems [22,23]. Nevertheless, the EC technique is expensive, subject to data gaps, and limited to relatively flat, large landscape regions, so cannot offer universal sampling of fluxes for all locations.

Remote sensing and proximal optical sampling methods can provide cost-effective, uniform sampling under conditions where eddy covariance techniques would be impractical. Satellite remote sensing combined with weather data have been used to model global carbon exchange for many years now, but these current models often disagree with local field measurements due to the coarse scale of their optical and meteorological inputs [24]. For effective carbon policy, fine-grained measurements are needed to match the scale of local land management practices. Recent advances in automation and low-cost optical sensors are making a local-scale optical sensing approach increasingly attractive. Recent studies show that the combined application of remote and proximal optical sensors provide the opportunity to monitor productivity across a wide range of spatial and temporal scales and offer the 
possibility to relate remote sensing measurements with carbon fluxes as a foundation for modeling and upscaling [25]. Networks such as SpecNet and EUROSPEC have been exploring the possibility of combining flux and spectral reflectance measurements for a more complete assessment of ecosystem function [26-28]. These collaborations have increased the availability of both optical and flux data, allowing for improved models linking remote sensing measurements and carbon fluxes. A crucial first step is to quantitatively evaluate optical methods in comparison to flux methods to enable proper model parameterization.

The most widely applied model for combining carbon fluxes and optical measurements is the Light Use Efficiency (LUE) model. Originating with the work of Monteith [29,30], more recent parameterizations have been used to estimate gross primary productivity (GPP) based on the equation:

$$
\mathrm{GPP}=\varepsilon \times \mathrm{APAR}_{\text {green }}
$$

where APAR green (absorbed photosynthetically active radiation) represents the amount of radiation absorbed by green vegetation, and $\varepsilon$ represents the efficiency with which that absorbed light is used by vegetation to fix carbon. To obtain annual GPP, the equation terms can be integrated (summed) over the full growing season [24,31].

$\mathrm{APAR}_{\text {green }}$ can be further defined or measured as the product of $f$ APAR green (the fraction of photosynthetically active radiation absorbed by green vegetation) and PAR (photosynthetically active radiation, also called the photosynthetic photon flux density, or PPFD):

$$
\mathrm{APAR}_{\text {green }}=f \mathrm{APAR}_{\text {green }} \times \mathrm{PAR}
$$

Damm et al. [32] reported that, especially in cropland and grassland, canopy structure and APAR covary in time during a seasonal cycle. Partitioning between photosynthetic and non-photosynthetic components of vegetation in APAR calculations significantly improves estimation of ecosystem productivity with respect to models driven by total $f$ APAR $[33,34]$. APAR green, a measure of green vegetation structure closely linked to green biomass or leaf area index, plays a dominant role in the model for most grassland ecosystems. The confusion of methods and LUE model definitions in the literature has led to uncertainty when comparing model results [34]. To clarify the terminology and to emphasize the role of green (not total) vegetation in driving light absorption for photosynthesis and productivity, we adopted the terminology recommended by Gitelson and Gamon [34] and included the subscript "green" when referring to fAPAR and APAR.

Light use efficiency $(\varepsilon)$ relates to vegetation physiology, and is presumably less important in determining seasonal GPP patterns for grasslands and other annual systems where canopy growth dominates the seasonal phenological signals detectable with remote sensing [35]. Consequently, most of the variability in grassland productivity can be explained by changes in APAR green [36] when the ecosystem is not stressed $[33,35,37]$. For this reason, we adopted the hypothesis of a constant $\varepsilon$ over the season (May-October) in our study.

The strength of the LUE model is related to the possibility of deriving its input values from remote sensing observations [24,38,39]. Several vegetation indices (VIs) have been used to estimate fAPAR $_{\text {green, }}$ most notably the normalized difference vegetation index (NDVI) [40]. When combined with PAR irradiance, either as a modeled or directly measured value (using PAR sensors), $f$ APAR green readily provides a reliable measure of $\mathrm{APAR}_{\text {green, }}$ the primary term in the LUE model (Equation (2)).

The rising interest in linking carbon flux measurements, proximal (in situ) spectral measurements and remote sensing data has motivated the establishment of a global network of experimental sites in various ecosystems that simultaneously collect optical and flux datasets [26,27]. A key issue in combining optical and flux measurements is the evaluation of temporal scale, as optical and flux measurements vary on different time scales [26]. To our knowledge, few studies explicitly consider the effect of temporal aggregation when comparing remote sensing and flux data, in part because many satellite sensors (e.g., the MODIS Aqua and Terra sensors) are in sun-synchronous orbit that 
limit the number of daily overpasses. In this study, we took advantage of the continuous nature of flux and optical data to enable an explicit consideration of temporal aggregation, as recommended by the SpecNet community [27].

The objectives of this study were to:

- $\quad$ assess the seasonal patterns of $\mathrm{CO}_{2}$ exchange, above-ground biomass accumulation, and optical properties of a prairie grassland ecosystem comparing different optical sampling techniques (NDVI $_{680,800}$ from field spectrometer measurements, proxy NDVI measurements from automated sensors on an "optical phenology station," and MODIS NDVI measurements);

- compare midday data aggregation periods for accurate prediction of fluxes from optical data;

- test different NDVI inputs and related biophysical parameters ( $f A P A R_{\text {green }}$ and $\left.A P A R_{\text {green }}\right)$ from both satellite and ground measurements as proxies for flux measurements using the LUE model;

- test the hypothesis of constant $\varepsilon$ over the entire season in grassland ecosystem; and

- illustrate the potential of optical data to gap-fill eddy covariance measurements.

\section{Materials and Methods}

\subsection{Study Site and Experimental Design}

The Mattheis Ranch is a 4977 ha working cattle ranch located near Duchess in southern Alberta, Canada, and is mostly characterized by native prairie vegetation. Recently, this site has become a research area managed by the Rangeland Research Institute (University of Alberta), offering the possibility of long-term monitoring of ecosystem dynamics under management regimes typical of this region. The climate of southern Alberta presents long winters and short, windy summers with extreme temperatures in both seasons, and peak precipitation periods occurring in early summer (June). The rest of the summer usually has lower precipitation, but summer rainfall regimes can vary markedly from year to year, with a similarly variable effect on productivity [12]. The management regime consisted of light, rotational grazing, as further described in Wang et al. [41].

Our study site centered on two eddy covariance tower locations designated "E5" (northern site, $50.9056 \mathrm{~N}, 111.8823 \mathrm{~W}$ ) and "E3" (southern site, 50.8671N, $111.9045 \mathrm{~W}$ ), situated about $4.5 \mathrm{~km}$ apart (Figure 1).

The two sites differed slightly in vegetation cover and microtopography; E5 appeared very flat and uniform, while the E3 landscape varied slightly more than E5 in microtopography and vegetation cover within the flux tower footprint [41], but was still a relatively uniform grassland-dominated site. The sites represent a typical dry mixed grass prairie community as described by Adams et al. [9]. The E5 soil is a clay loam, and the plant community is dominated by needle-and-thread grass (Hesperostipa comata), Junegrass (Koeleria macrantha), blue grama grass (Bouteloua gracilis), and western wheatgrass (Pascopyrum smithii). Pasture sage (Artemisia frigida) and scarlet mallow (Sphaeralcea coccinea) are the most common forbs, and silver sagebrush (Artemisia cana) is the primary shrub species [42]. In contrast, the soil at the E3 site is a sandy loam. Dominant grasses include sand grass (Calamovilfa longifolia), needle-and-thread grass (Hesperostipa comata), and low sedge (Carex stenophylla), while common forbs are scurf pea (Psoralidium lanceolatum), golden aster (Heterotheca villosa), and prickly-pear cactus (Opuntia polyacantha). Slight variations in topography allow forbs such as wild licorice (Glycyrrhiza lepidota) and golden bean (Thermopsis rhombifolia), and shrubs such as wild rose (Rosa woodsii) to flourish [42]. Due to these differences in vegetation, soil type and associated hydrology (not shown), these two sites provided a natural experiment encompassing two contrasting landscapes typical of southern Albertan rangelands. 

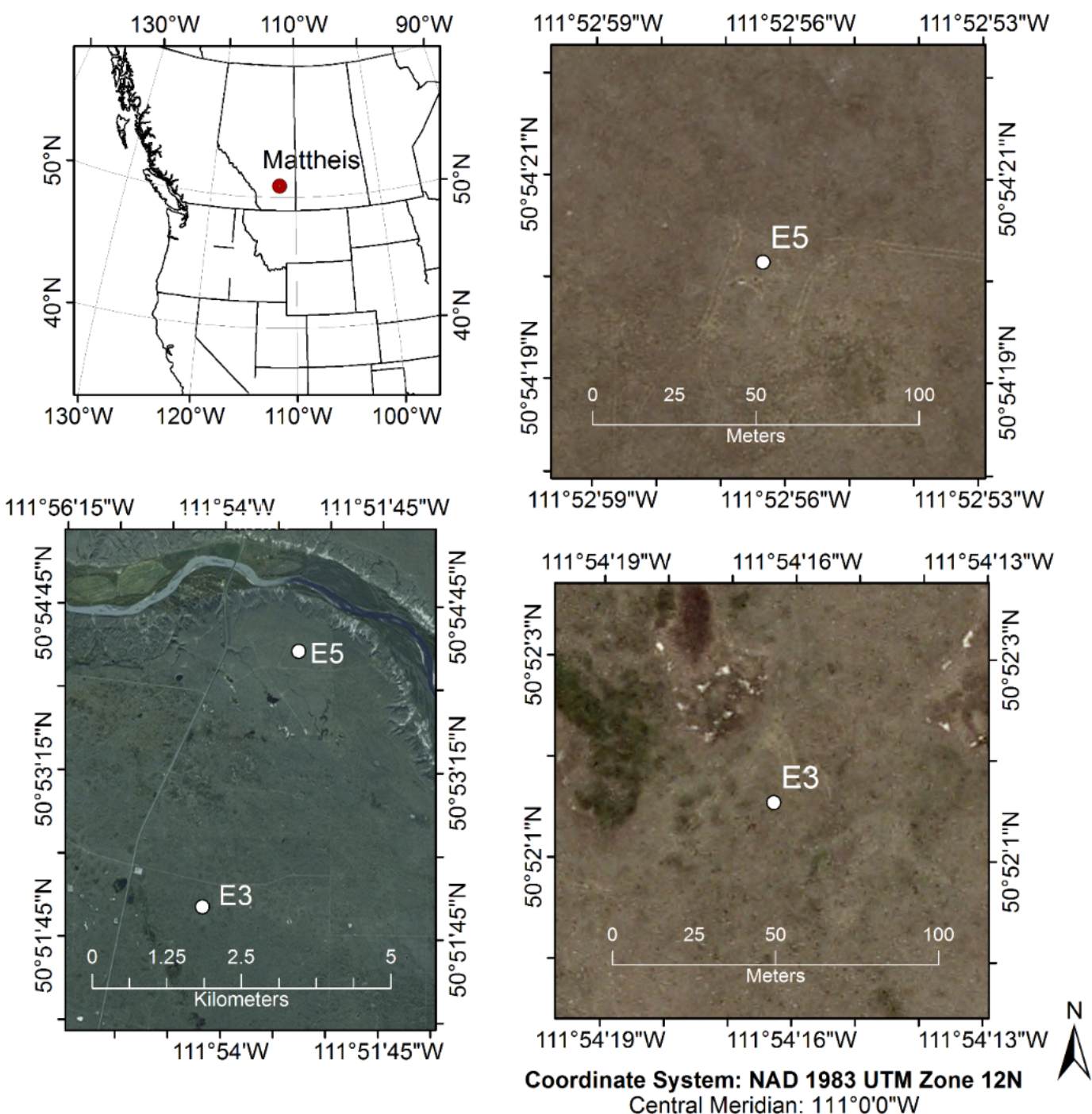

Figure 1. Map of study location (top left), with detail of study area (bottom left), showing the E3 and E5 calibration sites. Further details of each site are provided on the right. Image credits: ESRI, DigitalGlobe, GeoEye, i-cubed, Earthstar Geographics, CNES/Airbus DS, USDA, USGS, AEX, Getmapping, Aerogrid, IGN, IGP, swisstopo, and the GIS User Community.

The measurements at the two grassland sites (E3 and E5) included:

- $\mathrm{CO}_{2}$ flux measurements from eddy covariance at the E3 and E5 sites,

- continuous, proxy NDVI [27,43] from a set of 2-band radiometers, including PAR (photosynthetically active radiation) and PYR (pyranometer) sensors, comprising an "optical phenology station,"

- aboveground biomass samples from a 1 ha area around each flux tower site periodically collected following the sampling scheme reported in Figure 2,

- $\quad \mathrm{NDVI}_{680,800}$ measurements using a field spectrometer collected at regular intervals in the same area (1 ha) using a $10 \mathrm{~m}$ grid spacing (Figure 2),

- incident and reflected incoming PAR measurements at each calibration point (numbered circles, Figure 2), and

- MODIS satellite NDVI data downloaded for the study areas. 
Each phenology station was located approximately $10 \mathrm{~m}$ to the southeast of its corresponding flux tower. These two sites (E3 and E5) were monitored for two consecutive growing seasons (May-September) during 2012 and 2013.

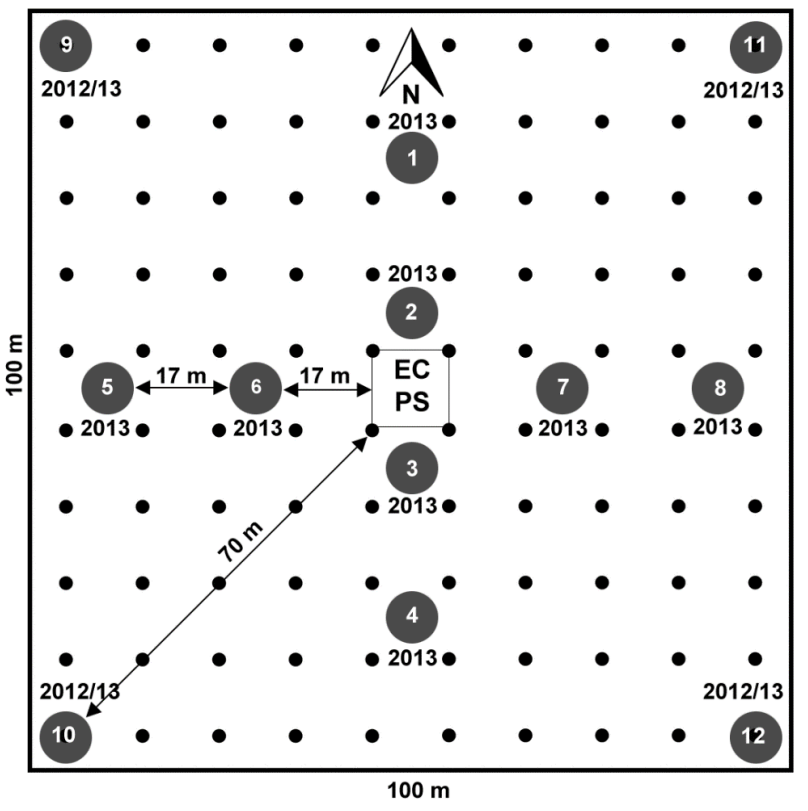

Figure 2. Optical and biomass sampling design around each eddy covariance (EC) and phenology station (PS) location. Canopy-level NDVI 680,800 was sampled at regular intervals within a one hectare region surrounding each flux tower using $10 \mathrm{~m}$ grid spacing (approx. 100 samples; sampling locations represented by black dots). Biomass sampling and $f \mathrm{APAR}_{\text {green }}$ calibration occurred at the locations indicated by numbered circles (1-12), with the sampling years indicated by each circle.

\subsection{Biomass Estimation}

From May to August 2012, vegetation samples were harvested from four biomass calibration points approximately every 20 days using a $30 \mathrm{~cm}$ diameter ring in both sites (E3 and E5) at a distance of $70 \mathrm{~m}$ from the tower in four directions (South-East, North-East, North-West, South-West) (Figure 2). The grass material within the ring was cut at ground level and placed into labeled paper bags. The following year, the sample size was increased, and samples from 12 points were collected from May to July about every 20 days (Figure 2). Note that each biomass sample was collected from a slightly different site within $2 \mathrm{~m}$ of each of the 12 locations indicated above (Figure 2) to avoid repeatedly harvesting the same locations. To develop calibrations between biomass, $f \mathrm{APAR}_{\text {green, }}$ and $\mathrm{NDVI}_{680,800}$, biomass samples were collected at each of the harvest sampling points just after the collection of $f$ APAR and reflectance measurements used to calculated $\mathrm{NDVI}_{680,800}$. Each sample was manually sorted into green biomass and brown biomass, put into an oven at $60{ }^{\circ} \mathrm{C}$ for $24 \mathrm{~h}$, and weighed. The selection was carried out considering the living tissue that was visibly green as green biomass and the visibly dead tissue as brown biomass. This selection of green and dead biomass allowed us to measure the current year's production, since the green tissue represented the current year's growth, and the dead tissue consisted of the previous year's growth. For each date, average green and total (green plus brown) above-ground biomass was calculated from the manually sorted and weighed biomass samples. For each sampling date, green biomass was calculated as the average of green biomass at all sampling locations (Figure 2), expressed as $\mathrm{g} \cdot \mathrm{m}^{-2}$. By providing a direct metric of productivity, this measure of biomass provided an independent check on the validity of the optical (NDVI) measurements and the resulting LUE model. 


\section{3. fAPAR green and $A P A R_{\text {green }}$ Calibration}

At each of the 12 calibration points (Section 2.2 above; numbered circles, Figure 2), we also measured incident, transmitted and reflected PAR (photosynthetically active radiation) using a light bar (AccuPAR LP-80, Decagon, Pullman, WA, USA) as well as NDVI 680,800 from spectrometer measurements (Figure 2). At each site, light bar measurements consisted of downwelling PAR above the canopy (S), upwelling PAR reflected from the canopy (R), downwelling PAR below the canopy (T), and upwelling PAR below the canopy (U). Ten measurements were made at each calibration point and averaged, then $f$ APAR was calculated, following the procedure described in Nassar et al. [44] and the equation:

$$
f \mathrm{APAR}=1-t-r+t r_{s}
$$

where $t$ is the fraction of radiation transmitted through the canopy $(t=\mathrm{T} / \mathrm{S}), r$ is the fraction of radiation reflected by the canopy $(r=\mathrm{R} / \mathrm{S})$, and $r_{s}$ is the reflectance of the soil surface $\left(r_{s}=\mathrm{U} / \mathrm{T}\right)$.

These $f$ APAR measurements were multiplied by the green:total biomass fraction to calculate a $f$ APAR $_{\text {green }}$ value (fraction of PAR absorbed by green canopy material) for comparison with the proxy NDVI values (phenology stations) and NDVI $_{680,800}$ values collected at each harvest site (Figure 2). To calculate the APAR green term of the LUE model (Equation (2)), we derived the following NDVI- $f$ APAR green relationships from the $f$ APAR calibration sites:

$$
\begin{aligned}
& \text { fAPAR }_{\text {green }}=\left(0.8799 \times \mathrm{NDVI}_{680,800}\right)-0.1394\left(R^{2}=0.79\right) \\
& f_{\text {APAR }} \text { green }=(1.3916 \times \text { proxy NDVI })-0.3603\left(R^{2}=0.82\right) \\
& \text { fAPAR }_{\text {green }}=(0.9879 \times \text { MODIS NDVI })-0.2131\left(R^{2}=0.79\right)
\end{aligned}
$$

In these equations, proxy NDVI and MODIS NDVI were simulated from narrowband reflectance (as described in Section 2.4 below). In the final model, we used Equation (5) (with proxy NDVI) since it yielded the best calibration (highest $R^{2}$ ). In accordance with Equation (2), continuous APARgreen, was calculated as the product of PAR (from phenology station) and $f$ APAR green values.

\subsection{NDVI Measurements}

\subsection{1. $\mathrm{NDVI}_{680,800}$}

Narrow-band reflectance measurements were obtained with a dual channel spectrometer (UniSpec-DC, PP-Systems, Amesbury, MA, USA), which has a spectral range of 305-1130 nm and $\mathrm{a} \approx 3 \mathrm{~nm}$ nominal bandwidth (10 $\mathrm{nm}$ full width at half maximum). The spectrometer was fitted with two optical fibers, one looking upward and one looking downward, enabling simultaneous sampling of downwelling irradiance and target radiance and correction for variable sky conditions [45]. The upward-looking detector was fitted with a hemispherical cosine head (UNI435, PP Systems, Amesbury MA, USA) and sampled downwelling radiation; the downward-looking detector was fitted with a fiber optic (UNI684, PP Systems, Amesbury MA, USA) and field-of-view restrictor (hypotube, UNI688, PP Systems, Amesbury MA, USA) and sampled upwelling radiation with a nominal field-of-view of approx. 20 degrees from a distance of approx. $2 \mathrm{~m}$.

The spectrometer sampling procedure involved walking a series of transects across a 1-hectare grid centered on the flux tower, with each sample approximately $10 \mathrm{~m}$ apart (Figure 2). This grid sampling was completed approximately every 20 days during the growing season within one hour of solar noon. This allowed us to calculate the $\mathrm{NDVI}_{680,800}$ of an area approximating the flux footprint and to compare the field spectral measurements with those derived from the MODIS satellite sensors. A separate study [41] demonstrated that, due to the uniformity of the landscape, the NDVI values of these different sampling regions were very similar, with an error of $4 \%$ or less. In addition to the grid sampling, the field spectrometer was also used to measure spectral reflectance at exactly the same 
location of each aboveground biomass sampling site for the purpose of NDVI-biomass calibration (numbered circles, Figure 2).

Spectral processing software (Multispec, http:/ / specnet.info) was used to calculate raw reflectance values, calculated as the ratio between upwelling surface radiance $\left(R_{\text {target }}\right)$ and downwelling solar irradiance $\left(I_{\text {downwelling }}\right)$ :

$$
\text { Raw reflectance }=R_{\text {target }} / I_{\text {downwelling }}
$$

The next step was to calculate a cross-calibration value comparing downwelling solar irradiance ( $\left.I_{\text {downwelling }}\right)$ to a $99 \%$ reflective white standard panel $\left(R_{\text {panel }}\right)$ (Spectralon, Labsphere Inc., North Sutton, $\mathrm{NH}, \mathrm{USA})$ :

$$
\text { Cross }- \text { calibration }=I_{\text {downwelling }} / R_{\text {panel }}
$$

This cross-calibration was then used to calculate a corrected reflectance value as follows:

$$
\mathrm{R}_{\text {corrected }}=\left(R_{\text {target }} / I_{\text {downwelling }}\right) \times\left(I_{\text {downwelling }} / R_{\text {panel }}\right)
$$

This application of the cross-calibration was corrected for optical differences among sensors and for changing irradiance [45]. Both target and panel readings were taken under similar illumination and sun angle conditions. White panel measurements were taken at the beginning and ending of every grid sampling procedure.

For $\mathrm{NDVI}_{680,800}$ calculations, reflectance was interpolated to 1-nm wavebands. $\mathrm{NDVI}_{680,800}$ was obtained from spectrometer grid data using the $680 \mathrm{~nm}$ waveband for the red region of the spectra and the $800 \mathrm{~nm}$ waveband for the infrared region, and was calculated using the following formula:

$$
\mathrm{NDVI}_{680,800}=\left(\rho_{800}-\rho_{680}\right) /\left(\rho_{800}+\rho_{680}\right)
$$

where $\rho$ represents the reflectance at a given waveband, and subscripts indicate the wavelength values used. $\mathrm{NDVI}_{680,800}$ was compared to green biomass and $f \mathrm{APAR}_{\text {green }}$ (see Sections 2.2 and 2.3), but because of the low sampling frequency (about every 20 days) was not compared to daily flux values or used directly in the LUE model. For $f A P A R_{\text {green }}$ calibration, reflectance spectra from the calibration sites were convolved against PAR, PYR (pyranometer), and MODIS NDVI band responses by multiplying each reflectance spectrum by the sensor band response for each wavelength, and dividing the summed product by the sum of the band responses across all wavelengths. These bands were then used to simulate proxy and MODIS NDVI values for calibration against $f$ APAR green (see Section 2.3 above).

\subsubsection{Proxy NDVI Measurements}

Each site was monitored with an optical phenology station consisting of a data logger (H21-001, Onset Computer Corporation, Bourne, MA, USA) and two-band radiometer mounted on a boom and tripod, $3 \mathrm{~m}$ above the ground, placed approximately 10 meters southwest of each tower. The sensors detected incoming light (irradiance) and reflected light from the canopy. One band consisted of two PAR sensors (S-LIA, Onset Computer Corporation) that measured the photosynthetic photon flux density (PPFD) within the PAR band (400-700 nm), and the other band consisted of two PYR sensors (S-LIB, Onset Computer Corporation) measuring irradiance or radiance across a spectral range from 300 to $1100 \mathrm{~nm}$. Both up- and down-looking sensors had cosine (nominally 180 degree) foreoptics, allowing us to sample a relatively large area $\left(\approx 100 \mathrm{~m}^{2}\right)$ immediately adjacent to the flux tower, but restricted to a small portion of the total flux footprint (typically $>1$ ha, with variations depending on windspeed and wind direction) [41]. This phenology station provided a continuous, high temporal resolution proxy NDVI by means of continuous broad-band reflectance in both PAR and PYR bands sampled every 1-min during the whole growing season and logged as 15-min averages, thus monitoring seasonal changes in the vegetation photosynthetic phenology [43]. Additionally, temperature and relative humidity were monitored via appropriate sensors (RH; S-THB-M002, Onset 
Computer Corporation) allowing rainy-day optical data to be identified and filtered from the dataset (see Section 2.6, below). To derive proxy NDVI values, each sensor pair had been previously cross-calibrated against one another by comparing both upward- and downward-looking sensors in an upward-looking (irradiance) configuration, yielding a coefficient that corrected for any sensor differences (typically less than 5\%). These coefficients were then applied to each sensor pair (PAR and PYR) prior to calculating proxy NDVI. Subsequent analyses used the 15-min averages (aggregated over different time periods from 1 to $5 \mathrm{~h}$ ) to calculate midday average $\mathrm{APAR}_{\text {green }}$ and proxy NDVI values for comparison with midday average net $\mathrm{CO}_{2}$ flux from the eddy covariance tower (Figure 3). Since 5-h aggregation periods yielded the highest correlation with $\mathrm{CO}_{2}$ flux (see Supplementary Materials), and fully encompassed the overpass times of the MODIS Aqua and Terra sensors, we chose that aggregation period for all subsequent analyses.

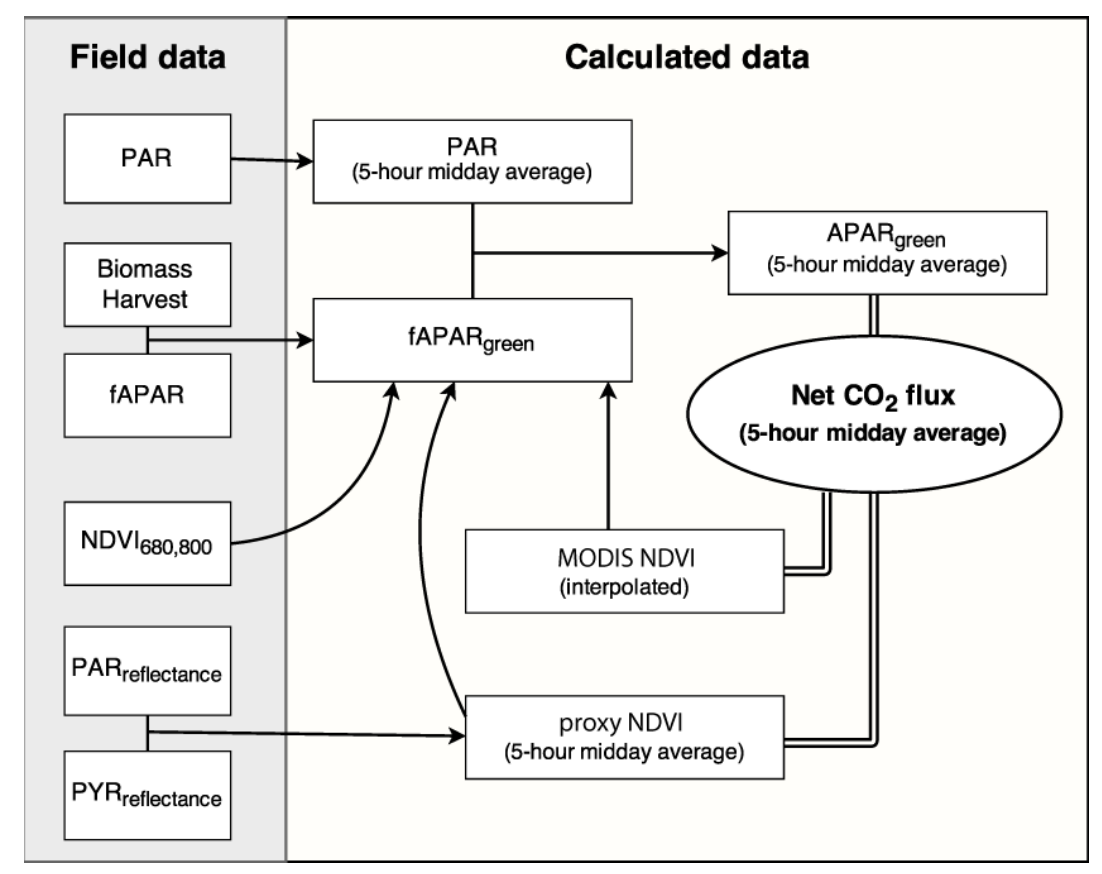

Figure 3. Experimental design, summarizing steps used in derivation of NDVI and APAR green (arrows), for comparisons with net $\mathrm{CO}_{2}$ fluxes (double lines). As indicated, $\mathrm{APAR}_{\text {green }}$ was estimated from the different NDVI metrics by regression of measured $f$ APAR $_{\text {green }}$ against proxy NDVI, and multiplying fAPAR $_{\text {green }}$ with PAR (photosynthetic photon flux density, measured with PAR sensors). Because the proxy NDVI provided continuous measurements, it was used to derive APAR $_{\text {green }}$ for comparison against $\mathrm{Net} \mathrm{CO}_{2}$ flux. Further explanation can be found in the text.

The phenology station data were used to compute a proxy NDVI $[27,43]$ following the formula:

$$
\text { proxy NDVI }=\left(\rho_{\mathrm{PYR}}-\rho_{\mathrm{PAR}}\right) /\left(\rho_{\mathrm{PYR}}+\rho_{\mathrm{PAR}}\right)
$$

where $\rho_{\text {PYR }}$ is the reflectance of the solar radiation (PYR band), calculated as the ratio of the reflected solar radiation to the incoming solar radiation and $\rho_{\mathrm{PAR}}$ is the reflectance of the photosynthetically active radiation (PAR band) calculated as the ratio between the reflected PAR and the incoming PAR. This provided a continuous proxy NDVI, which was then averaged over a 5 -h midday period (Figures 2 and 3) for comparison with the daily flux measurements. Using the calibration derived from the harvest sites (Equation (5)), the proxy NDVI time series was used to derive $f$ APAR green for the LUE model (Figure 3). 


\subsubsection{MODIS NDVI Measurements}

The NASA Terra and Aqua satellites, which have orbited Earth since 1999 and 2002, respectively, each carry a MODIS (Moderate Resolution Imaging Spectroradiometer) sensor. These satellites pass daily over most of Earth's surface and provide a nominal $250 \mathrm{~m}$ spatial resolution dataset in 36 spectral bands. NDVI values derived from MODIS NDVI products (MOD13Q1 from Terra and MYD13Q1 from Aqua) were downloaded from the Oak Ridge National Laboratory Distributed Active Archive Center website (http://daacmodis.ornl.gov/cgi-bin/MODIS/GLBVIZ_1_Glb/ modis_subset_order_global_col5.pl) The data were derived from a single MODIS pixel (nominally $250 \mathrm{~m} \times 250 \mathrm{~m}$ ) overlapping each eddy covariance tower locations for each site (E3 and E5). MODIS bands 1 (red, 620-670 $\mathrm{nm}$ ) and 2 (infrared, 841-876 nm) were used for MODIS NDVI calculation. For each MODIS sensor (Aqua and Terra), the 16-day aggregation period was based on the best observations during the composite period, and the actual collection date for each optimal observation was used to provide more accurate time series. The date-corrected time series was then interpolated to produce a daily MODIS value for comparison with daily flux values (Figure 3).

\section{5. $\mathrm{CO}_{2}$ Flux Measurements}

Net $\mathrm{CO}_{2}$ fluxes were measured using the eddy covariance (EC) technique [21]. Identical EC flux towers were deployed at our E3 $\left(50.8672^{\circ},-111.9045^{\circ}\right)$ and E5 $\left(50.9057^{\circ},-111.8823^{\circ}\right)$ grassland sites. Sites exhibited uniform vegetation cover (described above), providing measureable fluxes from all wind directions (i.e., the flux footprint) except those passing through the tower structures. Each tower was equipped with an open-path infrared gas analyzer (IRGA; LI-7500, LI-COR, Lincoln NE, USA) and a three-dimensional sonic anemometer (CSAT3; Campbell Scientific, Logan UT, USA) to quantify vertical $\mathrm{CO}_{2}$ fluxes. Each EC sensor was affixed at $2.9 \mathrm{~m}$ (E3 site) and $3.0 \mathrm{~m}$ (E5 site) above ground level and each IRGA was horizontally separated $15-17 \mathrm{~cm}$ from each sonic anemometer. All raw EC fluxes were measured at a sampling rate of $10 \mathrm{~Hz}$. Other sensors to quantify environmental conditions and weather were also fixed to each tower to measure half-hour averages of, for example, air temperature, relative humidity $(\mathrm{RH})$ and soil conditions. All collected data were stored by a datalogger (CR5000, Campbell Scientific).

EC data were analyzed using the software package EddyPro (LI-COR, v. 5.1) to quality check raw data, remove outliers and apply standard corrections to calculate corrected vertical fluxes of $\mathrm{CO}_{2}$. Raw $10 \mathrm{~Hz} \mathrm{CO}_{2}$ fluxes were preconditioned by eliminating data spikes greater than 3.5 standard deviations $(\sigma)$, temporary drop-outs $(10 \%$ per bin), and heavily-skewed data $(+2>x<-2)$. Anemometer tilt (mean pitch: E3 $=-1.6^{\circ}$; E5: $+1.5^{\circ}$ ) was corrected using a double rotation by forcing lateral and vertical wind components to zero. Data were removed when the time lag between measurements of the anemometer and IRGA exceeded $\pm 0.4 \mathrm{~s}$. Flux data were further detrended using a block-averaging approach over half-hour time increments. Calculated fluxes were corrected for density fluctuations using the Webb et al. [46] procedure. High-pass spectral corrections were implemented after Moncrieff et al. [47], while low-pass spectral corrections, integrating in-situ conditions to determine system cut-off frequencies, were used after Ibrom et al. [48]. Fluxes were further rejected when EC sensors malfunctioned or were affected by moisture, when wind passed through the tower before contacting EC sensors, or when friction velocities fell below $0.1 \mathrm{~m} \cdot \mathrm{s}^{-1}$ (after Wille et al. [49]). Turbulence tests using the approach of Mauder and Foken [50] were used to remove the poorest-quality fluxes (level 2) when they did occur. Half-hour fluxes below $-3 \sigma$ or above $+3 \sigma$ were considered outliers and removed. Corrections applied to daytime data resulted in the removal of $23.33 \%$ of all calculated fluxes across all EC measurements at both sites. For final comparison with optical data and derived biophysical parameters (proxy NDVI and APAR green), a midday average net $\mathrm{CO}_{2}$ flux was calculated based on a 5-h average, matching the period of averaging used for optical data (Figure 4). 


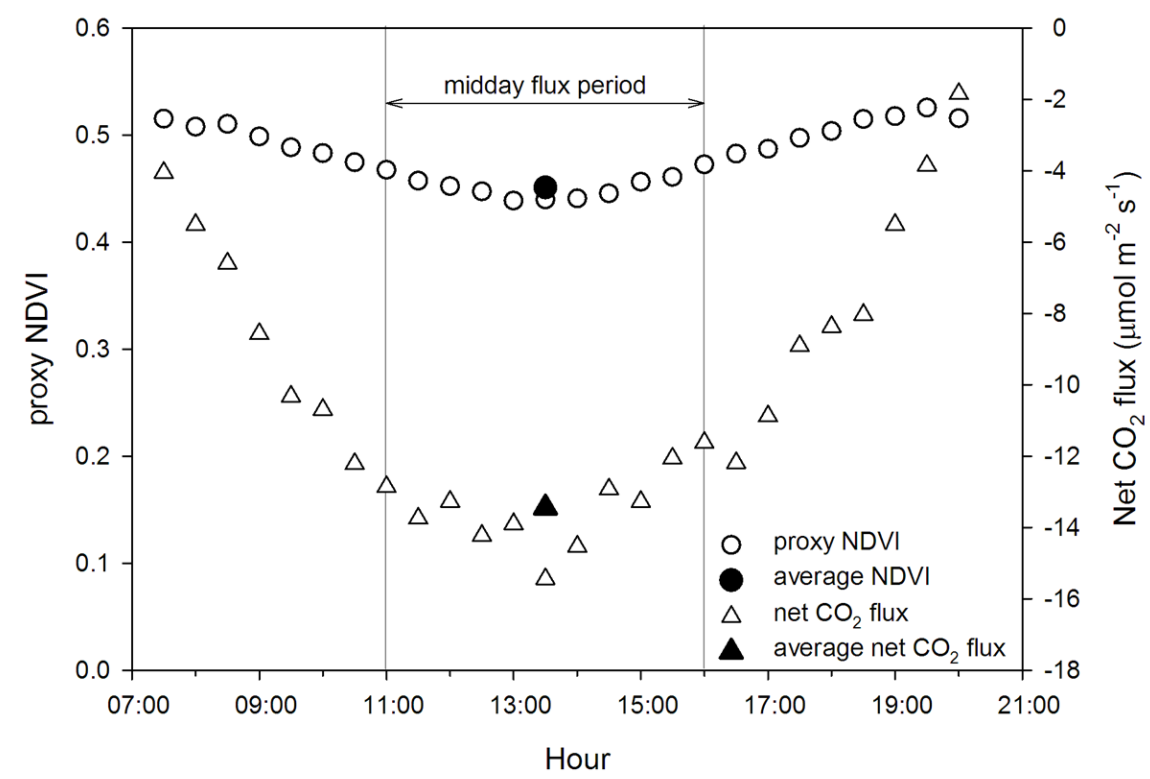

Figure 4. Sample diurnal course of proxy NDVI (from phenology station, circles) and net $\mathrm{CO}_{2}$ flux (from eddy covariance, triangles), showing average values (open symbols) calculated for the 5-h midday period (arrow between two vertical lines). See Methods and Supplemental Materials for further details on averaging (aggregation). Data from site E3, 7 June 2012.

\subsection{Filtering and Averaging Process}

Preliminary analysis of the optical data indicated invalid proxy NDVI values during periods of rainfall. These periods were easily detectible by evaluating relative humidity (RH) values. Proxy NDVI values associated with $\mathrm{RH}$ values greater than $76 \%$ tended to be outliers (data not shown) and were discarded. Similarly, automatic gain control (AGC), an IRGA diagnostic value, identified obstructions blocking the sensor's optical path. Water droplets, rime, dew, dust or pollen on the optical path impede sensor function and reduce data quality. Proxy NDVI data with associated AGC values greater than $64 \%$ were filtered from the dataset. To achieve data comparable to the MODIS values, a midday 5-h averaging (aggregation) was also applied to both proxy NDVI and flux data. In preliminary analyses, temporal averaging of proxy NDVI over $5 \mathrm{~h}$ (Figure 4) reduced short-term variability and clarified seasonal patterns. The impact of temporal aggregation was quantified by calculating the $R^{2}$ for the three time intervals considered (1,3,5 h midday periods). $R^{2}$ values increased from 1 - $\mathrm{h}$ to $5-\mathrm{h}$ averaging periods considering the whole season; similar results were found when considering green up and senescence periods separately (Table S1, Supplementary Materials). Since the relationship between proxy NDVI and net $\mathrm{CO}_{2}$ flux showed the best fit using the 5-h aggregation period (Table S1), and encompassed the MODIS overpass times, this time period was used in all subsequent analyses of proxy NDVI.

\subsection{Gap Filling}

One objective was to test the utility of optical data as a proxy of EC flux measurements, thus allowing gap-filling of the flux dataset. Non-gap-filled flux data were augmented by both filtered proxy NDVI data (providing the most continuous time-series of all three NDVIs used in this study, but not necessarily the most spatially representative NDVI) and MODIS data (providing a less continuous, but more spatially representative NDVI). The relationships between these different NDVIs and fluxes were then used to estimate missing flux data by applying several parameterizations of the LUE model (Equation (1)), each assuming an invariant efficiency $(\varepsilon)$ but using variable NDVI inputs to

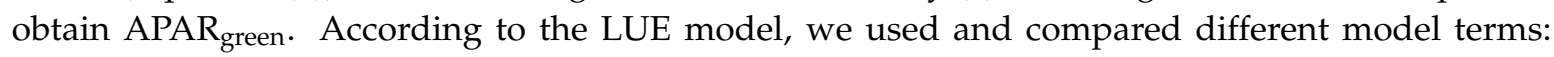
parameterizations ranged from simple NDVI (proxy NDVI and MODIS NDVI) to APARgreen. 
When comparing proxy NDVI to $\mathrm{CO}_{2}$ fluxes, both datasets were averaged for a 5-h interval around solar noon (11 am-4 pm; Figure 4) and these values were used as the daily value for flux and proxy NDVI, respectively. These midday average values were then used to model and fill data gaps in the flux data from optical measurements.

When using MODIS NDVI values, NDVI for each day over the entire season was calculated through a linear interpolation of actual date values from MODIS NDVI products (MOD13Q1 from Terra and MYD13Q1 from Aqua). The relationships between daily interpolated MODIS NDVI and net $\mathrm{CO}_{2}$ fluxes were then used to estimate flux data throughout 2012 for comparison with the proxy NDVI method.

Lastly, the midday average APAR green was calibrated against midday average net $\mathrm{CO}_{2}$ flux (Figure 3). The relationships between $\mathrm{APAR}_{\text {green }}$ and net $\mathrm{CO}_{2}$ flux were used to estimate midday flux data for 2012, and to gap-fill missing flux data. Finally, measured fluxes were compared with the gap-filled, modeled fluxes based on proxy and MODIS NDVI (Figure 3).

\section{Results}

\subsection{Seasonal Patterns of $\mathrm{CO}_{2}$ Exchange, Above-Ground Biomass, and NDVI Measurements}

At both sites, NDVI values obtained from the three different methods all showed similar patterns over the summer growing season, reaching peaks within the first half of July, while green biomass showed maximum values later in the month (Figure 5). An exception was a single MODIS Terra NDVI value in each year (8 July 2012 and 11 July 2013) that yielded one anomalously high NDVI value for each site and date (Table 1, and Figure 5). In most cases (particularly in 2012), the E3 site showed slightly higher productivity than the E5 site, demonstrated by the generally higher NDVI values for E3 (Table 1). In most cases, higher values of NDVIs occurred in 2013 as compared with 2012 (Figure 5, Table 1). A particularly low peak proxy NDVI value in E5 during 2012 (asterisk, Table 1) was the result of a mid-season data gap (spanning from 26 June to 27 August 2012). In general, MODIS Terra values were higher than the corresponding Aqua values, and MODIS values were higher than the ground-based NDVI values, in agreement with previous studies (e.g., [51]).

Table 1. Peak NDVI values and standard deviation ( $\sigma$ ) in 2012 and 2013 for both sites (E3 and E5), obtained with $\mathrm{NDVI}_{680,600}$ (grid sampling method), proxy NDVI (phenology station), and MODIS satellite (AQUA and TERRA sensors). The asterisk ${ }^{*}$ ) indicates an anomalously low peak value due to missing mid-season data (spanning 26 June-27 August 2012).

\begin{tabular}{ccccccccc}
\hline \multirow{2}{*}{ Peak NDVI Values } & \multicolumn{4}{c}{2012} & \multicolumn{5}{c}{$\mathbf{2 0 1 3}$} \\
\cline { 2 - 9 } & E3 & $\sigma$ & E5 & $\sigma$ & E3 & $\sigma$ & E5 & $\sigma$ \\
\hline NDVI $_{680,800}$ & 0.54 & 0.09 & 0.51 & 0.06 & 0.60 & 0.09 & 0.59 & 0.06 \\
Proxy NDVI & 0.56 & 0.01 & $0.47^{*}$ & 0.03 & 0.58 & 0.02 & 0.59 & 0.02 \\
MODIS NDVI-Terra & 0.69 & - & 0.60 & - & 0.68 & - & 0.66 & - \\
MODIS NDVI-Aqua & 0.61 & - & 0.53 & - & 0.58 & - & 0.59 & - \\
\hline
\end{tabular}




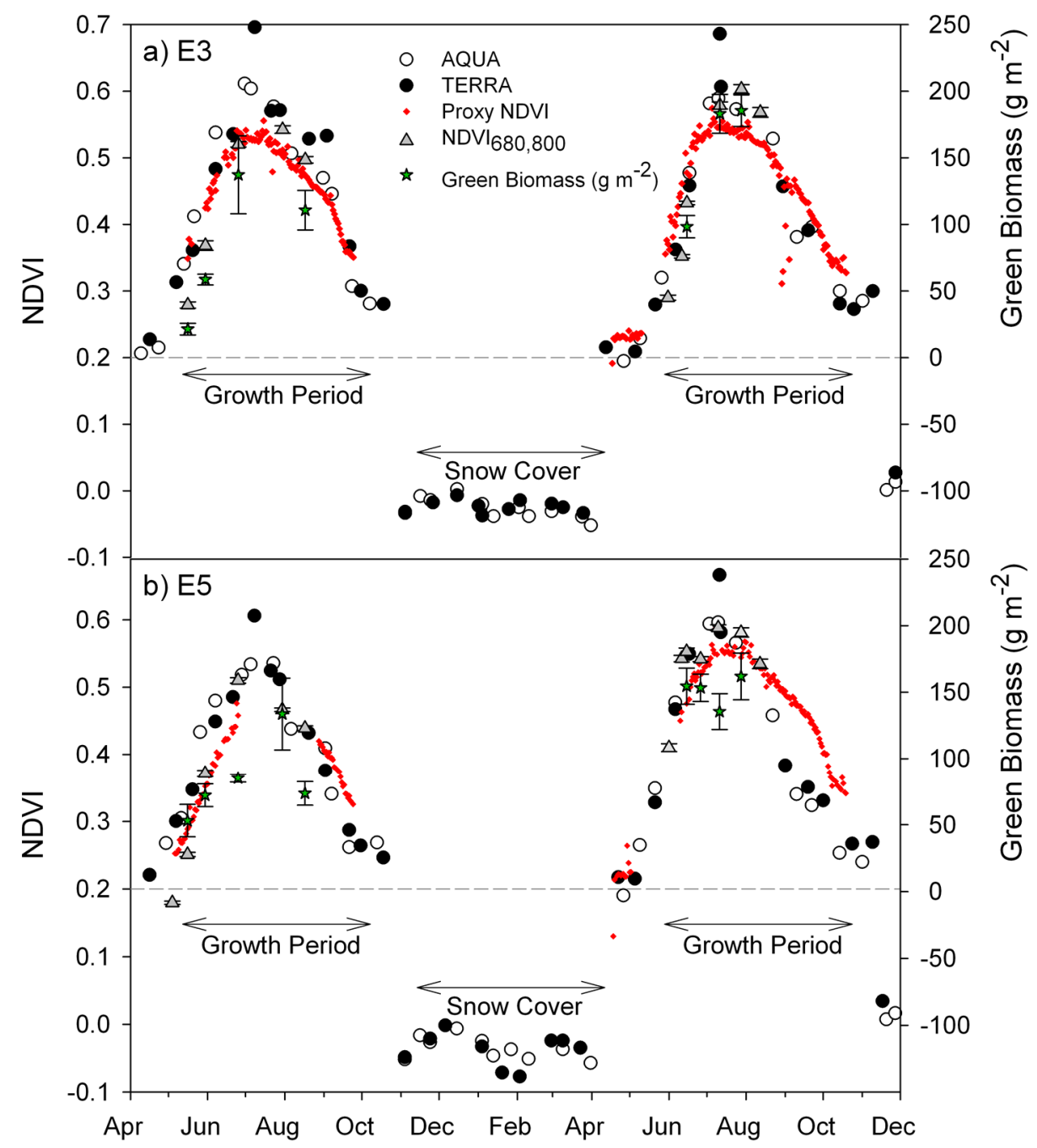

Figure 5. Time series (2012-2013) of $\mathrm{NDVI}_{680,800}$ collected from spectrometer with grid method, proxy NDVI from 2-channel sensors on phenology station (5-h averaged), MODIS NDVI (Aqua and Terra sensors), green biomass, at (a) E3 site; and (b) E5 site. Low (<0) NDVI values due to winter snow cover.

\subsection{Green Biomass Estimation Using Different NDVI Formulations}

Strong correlations emerged between each of the NDVI variants and green biomass (Figure 6). No significant differences occur between the slopes and the intercepts of the relationships for E3 and E5, thus allowing us to fit a single regression to the NDVI- green biomass data from both sites. Of the three NDVIs, the $\mathrm{NDVI}_{680,800}$ yielded a slightly stronger correlation $\left(R^{2}=0.82\right)$ than the proxy $\left(R^{2}=0.73\right)$ or MODIS $\left(R^{2}=0.73\right)$ NDVIs (Figure 6). All the relationships were statistically significant, showing $p$ values $<0.01$. 


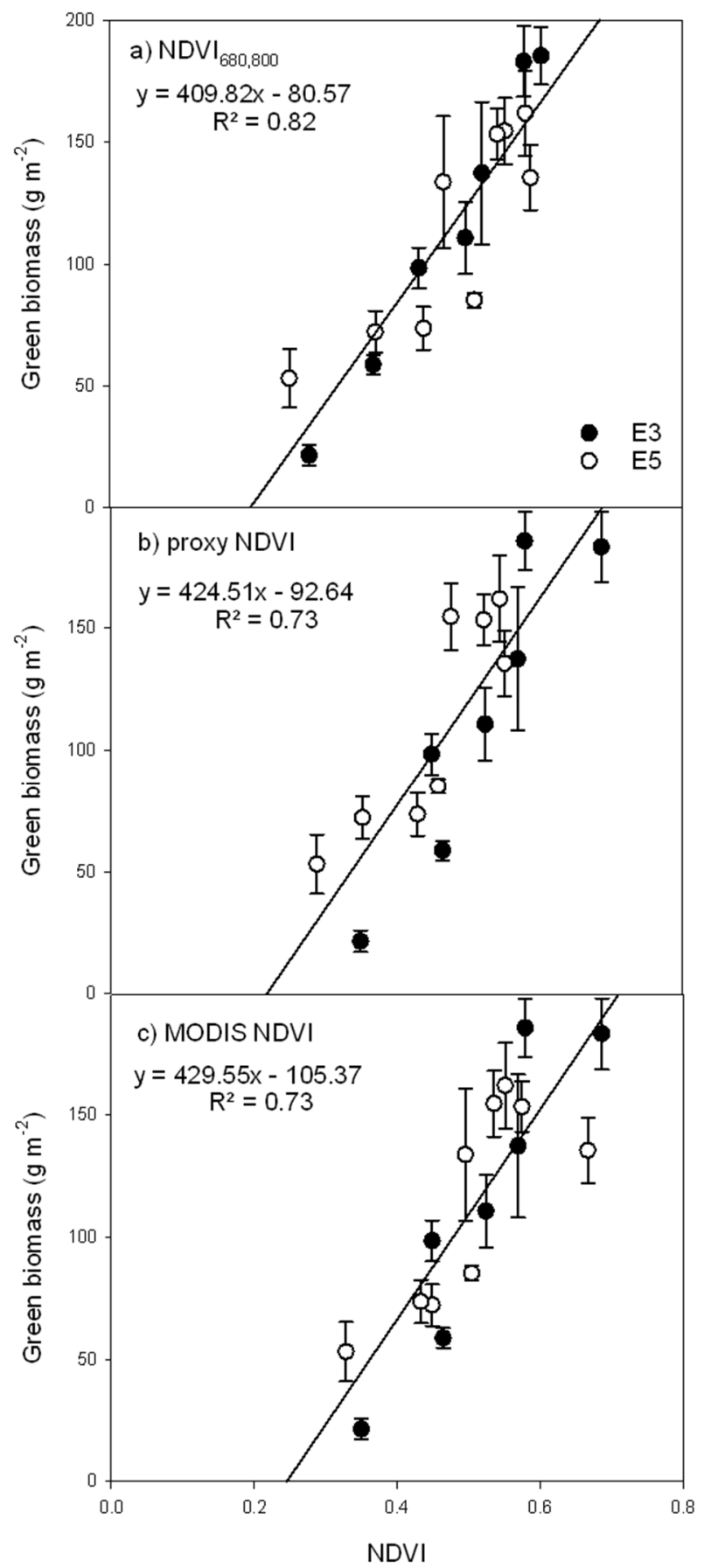

Figure 6. Correlations between green biomass and (a) $\mathrm{NDVI}_{680,800}$; (b) proxy NDVI (5 h averaged) and (c) MODIS NDVI for both E3 (black dots) and E5 sites (white dots) in 2012 and 2013. Error bars for green biomass are expressed as standard error of the mean. Resulting equations and correlations $\left(R^{2}\right.$ values) are indicated for each fit above.

\subsection{Parameterization of the LUE Model Using Proxy NDVI, MODIS NDVI and APAR green}

Figures 7 and 8 present the different approaches in flux-optical comparison, LUE model testing, and subsequent gap-filling of the flux dataset using optical datasets, including results based on proxy NDVI (panel a), MODIS NDVI (panel b), or APAR green derived from proxy NDVI (panel c). For this purpose, only results from the E3 site during 2012 were selected because this site and year had the fewest gaps in the optical measurements. To explore the possible effect of hysteresis in our datasets, 
relationships between flux and NDVI (or APAR green) are presented for the whole season (single fit) and for the green up phase and the maturity phase separately (separate fits). In this analysis, we used the peak flux value of the season to separate the season in the two parts. Better model estimates (higher $R^{2}$ values) were obtained when separate equations were used for the two parts of the season (Figure 7), indicating seasonal hysteresis in the flux-NDVI and flux-APAR green relationships. Flux model estimates derived from MODIS NDVI or APAR green (based on proxy NDVI) yielded slightly better agreement with measured fluxes than the estimates based on proxy NDVI (Figure 7).
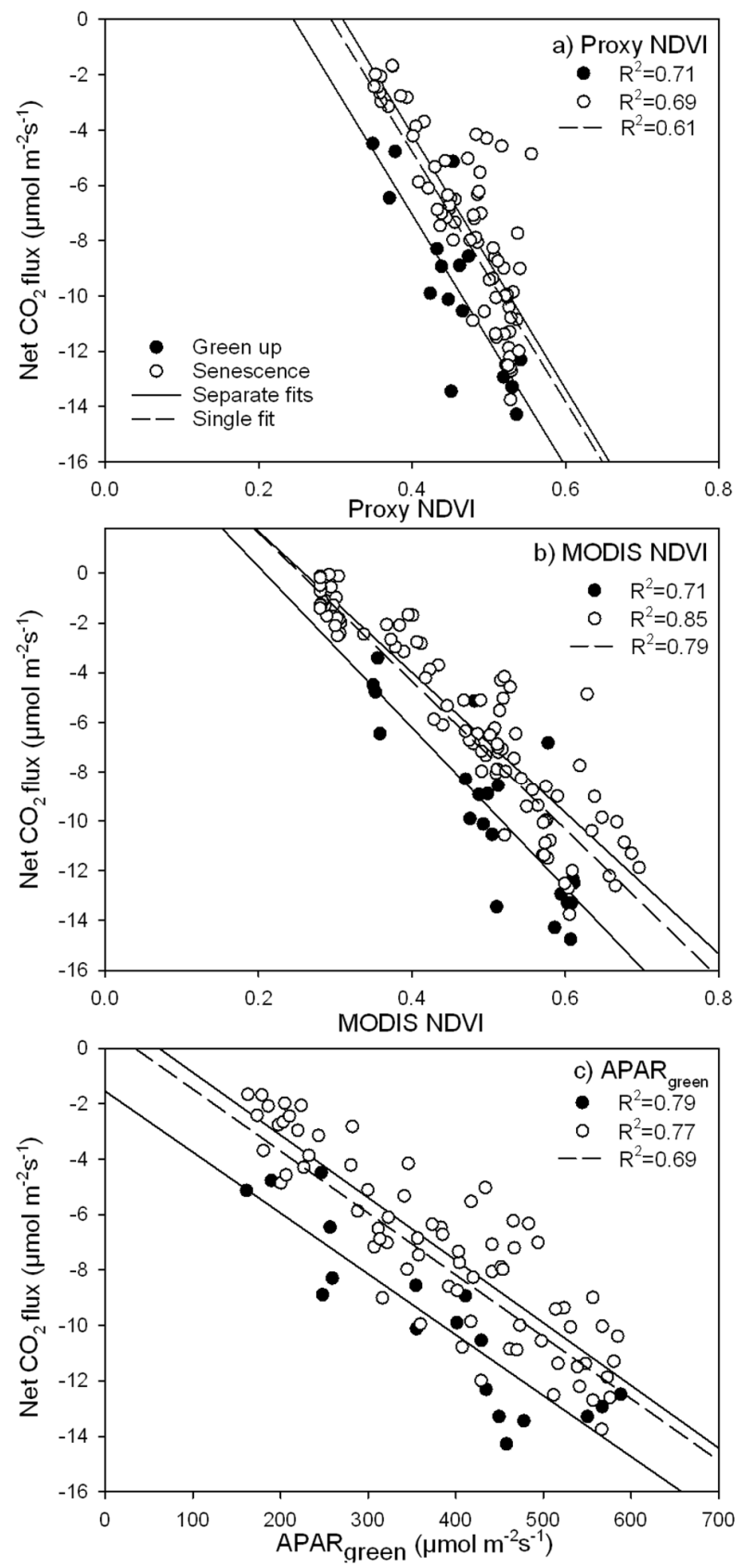

Figure 7. Relationship between proxy NDVI (5 h average, panel a); MODIS NDVI (panel b); APAR green (panel c) and filtered net $\mathrm{CO}_{2}$ fluxes (5 h average) for the $\mathrm{E} 3$ site in 2012. Fits are shown for the whole season (dashed line), for the green-up phase (black dots, solid line), and for the senescence phase (white dots, solid line). $R^{2}$ values are reported for each panel considering the whole season (dashed line), the green-up phase (black dots) and the senescence phase (white dots). $p$ values are $<0.001$ for all the relationships. 
The resulting time trends of modeled and measured fluxes using these two approaches (whole-season vs. two halves) are shown in Figure 8. Regardless of the model formulation, a single fit for the whole season tended to underestimate fluxes in the first half of the season and overestimate them in the second, and separate fits improved the agreement (Figure 8). In our final exercise, we used APAR green as independent variable and net $\mathrm{CO}_{2}$ flux as a dependent variable to derive a modeled flux (Figures $7 \mathrm{c}$ and $8 \mathrm{c}$ ). Unlike NDVI, APAR green also explicitly considers the dynamic variation in PAR irradiance (i.e., PPFD), and thus incorporated hourly and day-to-day variation in illumination. Relative to the proxy NDVI (from which it was derived), the APAR green-based model yielded a better fit with measured fluxes. The APAR green-based model also yielded more dynamic patterns of flux measurements relative to NDVI-based models ( $c f$. Figure $8 c$ to Figure $8 \mathrm{a}, \mathrm{b}$ ).
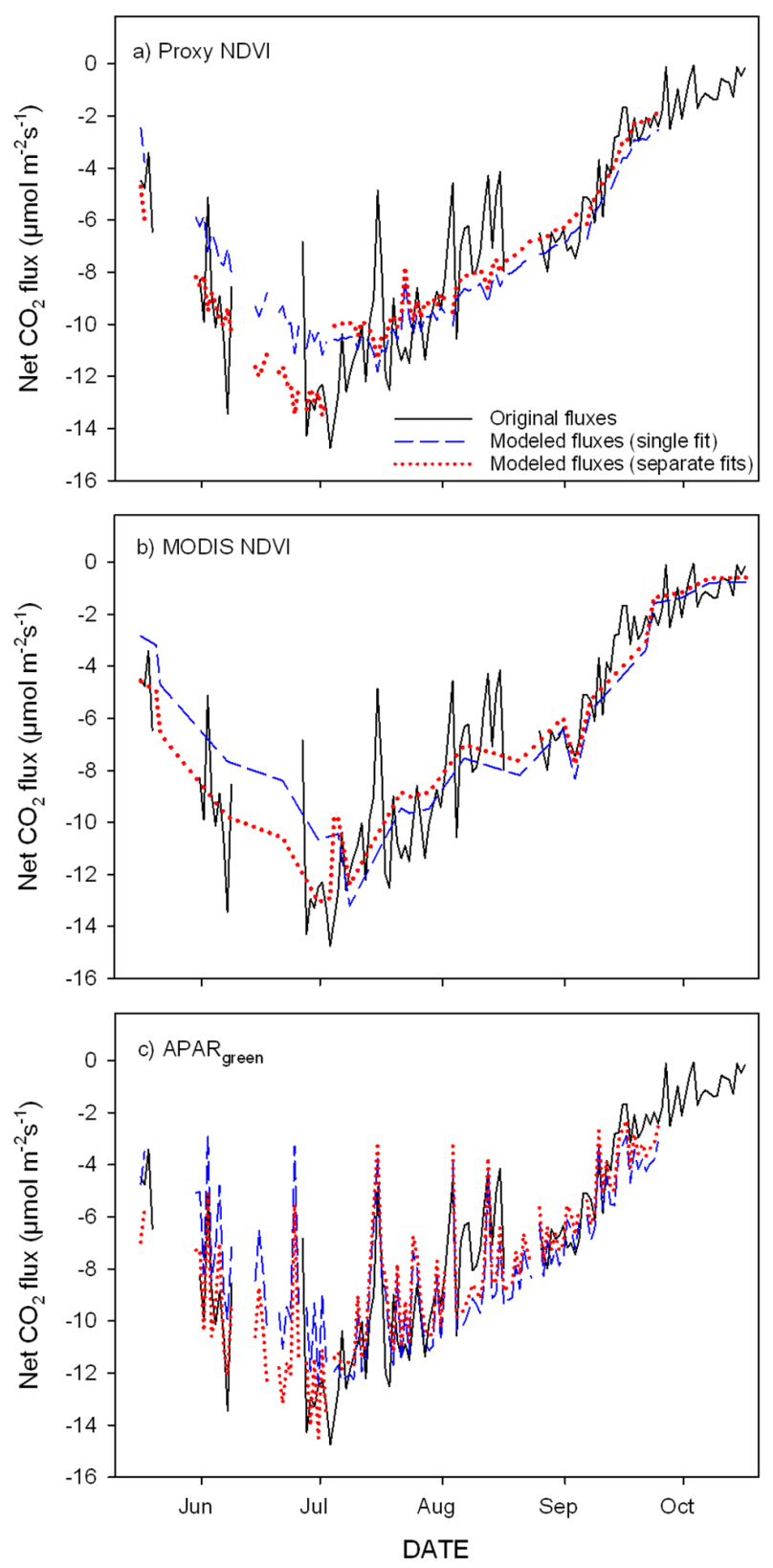

Figure 8. Time series of observed and modeled net $\mathrm{CO}_{2}$ fluxes based on proxy NDVI (panel a); MODIS NDVI (panel b); and APAR green (panel c). The original fluxes are shown as solid lines. Fluxes modeled using a single fit are shown as dashed lines, and fluxes modeled using two separate fits are shown as dotted lines. All results are for the E3 site in 2012. 


\section{Discussion}

Eddy covariance measurements, while they provide the "gold standard" for net $\mathrm{CO}_{2}$ flux measurements, are often affected by a number of problems, including instrumentation malfunctioning or low friction velocity, which can cause long data gaps. For this reason, several methods have been implemented to overcome periods of missing data [52-54]. The novelty of our approach lies in the particular combination of sensors used and in the comparison of different methods of obtaining NDVI as an input to the LUE model. This demonstrates the possibility of modeling and filling the gaps in a carbon flux dataset using empirical methods based on irradiance and spectral reflectance measurements. We address the data aggregation in the time domain and take advantage of flux station meteorological variables to filter optical measurements, illustrating how one dataset can be used to inform the processing of another.

Over the years, NDVI has emerged as a widely used reflectance index for detecting seasonal changes related to photosynthetic activity [37,55-58]. The effectiveness of NDVI as a metric of green biomass and as a useful parameter in a simple expression of the LUE model for a grassland ecosystem is confirmed in our study. The strong correlations between NDVI, APAR green, and midday $\mathrm{CO}_{2}$ flux for this prairie grassland provide a strong foundation for using optical measurements to model fluxes and gap-fill eddy covariance data, as proposed by Wohlfahrt et al. [54]. Our findings are in agreement with past studies that have shown good correlations between NDVI and green biomass, $\mathrm{APAR}_{\text {green, }}$ or total canopy chlorophyll content for many ecosystems [37,59-61]. Strong agreements between NDVI or NDVI-based modeled fluxes and eddy covariance measurements, particularly for ecosystems dominated by annual grasslands, are reported by similar studies $[37,60,62]$. These observations illustrate the utility of combining optical and flux measurements to characterize seasonal photosynthetic patterns.

The best relationship with NDVI and green biomass was established with $\mathrm{NDVI}_{680,800}$, but similar, strong patterns were found for all NDVI formulations (Figure 6). More work would be needed to understand the slight differences, which are presumably related to the different band formulations, temporal sampling periods, solar angle influence, or footprints of the three NDVI methods. Despite its broad-band formulation, proxy NDVI was able to depict most of the seasonal variability in net $\mathrm{CO}_{2}$ flux, and had the benefit of continuous sampling (similar to eddy covariance sampling). This outcome highlights the utility of broadband proxy NDVI for monitoring seasonal photosynthetic activity ("photosynthetic phenology") using a set of simple, inexpensive optical measurements [43]. These findings confirm that, for the purpose of measuring the seasonal course of photosynthetic activity in grassland ecosystems, broadband dual channel low-cost sensors can replace more complex and expensive hyperspectral sensors at eddy covariance sites when the budget is limited $[27,43,63,64]$. Of the three NDVI methods used, the proxy NDVI had the most limited sampling footprint (estimated at $\approx 100 \mathrm{~m}^{2}$ ), which might explain why it sometimes deviated from the other methods in the depiction of seasonal trends (Figure 5), and why it yielded slightly lower agreement with measured fluxes relative to MODIS NDVI (Figure 7). Further study with mobile sensors or fixed arrays of several proxy NDVI sensors located within the flux tower footprint would possibly improve the agreement with fluxes and clarify this question.

Several versions of the LUE model driven by satellite remote sensing of NDVI have been in wide use for many years $[24,31,65,66]$. While these models can depict broad global patterns, their agreement with local field measurements varies considerably across ecosystems or with different model formulations $[67,68]$. In fact, the selection of input to key parameters (e.g., PAR, fAPAR, APAR, $\varepsilon$ ) or their precise definitions (e.g., whether APAR and fAPAR are based on total or green canopy material) can broadly affect the results $[34,69]$. Site-specific studies incorporating proximal optical measurements can offer insights into these causes of variation. Several recent studies have focused on estimation of carbon dioxide fluxes using proximal optical measurements as proxies for $\mathrm{CO}_{2}$ fluxes $[54,60,63]$. However, a universal LUE model parameterization to estimate fluxes from proximal optical measurements for all ecosystems, while often discussed, does not yet exist [34,35]. Despite 
these limitations, it is clear that simple models that use linear relationships between fluxes and greenness indices such as those used in our study can successfully be used to estimate seasonal patterns of $\mathrm{CO}_{2}$ flux for certain ecosystems [70].

In our study, we compared the estimates of carbon fluxes using different predictor variables (proxy NDVI, MODIS NDVI and APAR green derived from proxy NDVI), which reproduced the seasonal net $\mathrm{CO}_{2}$ flux patterns with varying degrees of fidelity. This experiment allowed us to show that the APAR green-based method improved the estimates over NDVI alone. The proxy and MODIS NDVI methods could not explain all flux variability since they could not capture high-frequency flux changes due to irradiance dynamics. Unlike NDVI, APAR green is not only influenced by canopy structure, but also incorporates PAR irradiance (PPFD) [34]. Consequently, the incorporation of PAR irradiance (PPFD) in the relationship better captures the light dynamics affecting fluxes. This is probably one

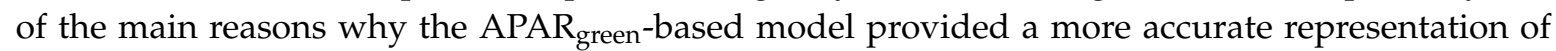
day-to-day variation in net $\mathrm{CO}_{2}$ fluxes than NDVI alone (Figure 8). While similar findings have been reported in some cases [71], other studies [64] have sometimes reported the opposite, finding that incorporation of PAR to yield APAR degrades agreement with $\mathrm{CO}_{2}$ fluxes relative to NDVI or $f$ APAR alone. The reasons for these discrepancies deserve further consideration, and could partly result from methodological differences, or the degree of stress (and variation in light-use efficiency), which can be assessed by the shape of the APAR green-flux curve. Additionally, the period of data aggregation could also affect these relationships, as the effects of including PAR are often more readily visible at fine scales (Figure 8). In general, while validation of modeled productivity using in situ measurements provides essential information on model performance, sampling strategies and methodological differences in data collection complicate comparability [72]. One benefit of the proxy NDVI method used here is that it can provide an objective and repeatable sampling method that removes much of the subjective choices often used in field sampling. On the other hand, a limitation of this proxy NDVI method is its relatively limited footprint, which could be addressed by networking multiple sensors.

The simple regression approach used in our study appears to work particularly well in ecosystems characterized by strong seasonal dynamics in above-ground green biomass such as grasslands and croplands [37,59,60,62,63]. In our grassland ecosystem, where seasonal $\mathrm{CO}_{2}$ fluxes largely scaled with canopy development (e.g., as measured by green, above-ground biomass, Figures 5 and 6), an

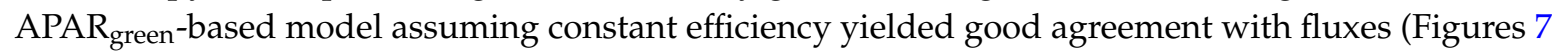
and 8), despite our ignoring the efficiency $(\varepsilon)$ term in the LUE model. In the literature, there is not a universal agreement on implementing $\varepsilon$, and this lack of a standard approach or definition for $\varepsilon$ has recently been addressed by Gitelson and Gamon [34]. In past studies, $\varepsilon$ has been assumed constant for all vegetation [56], fixed for each vegetation type (varying among different plant communities) $[69,73]$ or variable depending both on vegetation type and stress linked to environmental factors [24]. As has been discussed elsewhere [74], we would not normally expect very large variations in efficiency $(\varepsilon)$ over the season in grassland ecosystems. For this largely deciduous ecosystem, $\mathrm{CO}_{2}$ fluxes can be

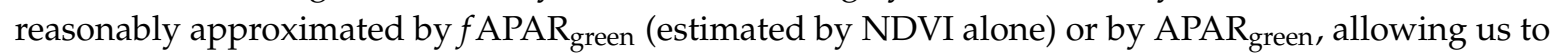
assume a constant efficiency $(\varepsilon)$ over much of the growing season. This supports the hypothesis that, in these annual ecosystems, controls on ecosystem fluxes are largely related to canopy structure, with relatively little physiological control evident [35]. These findings are in agreement with a broad range of studies that note strong relationships between $\mathrm{CO}_{2}$ fluxes and green canopy structure, expressed

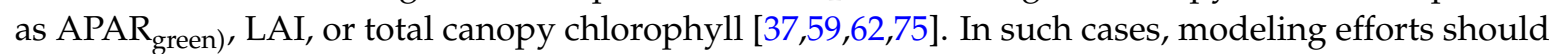
focus primarily on accurate estimation of the APAR green term in the LUE model.

We note that not all ecosystems lend themselves to such simple analyses. In many cases, a simple APAR green-based model based may be insufficient, particularly for evergreen ecosystems where dynamic light-use efficiency can be an important determinant of $\mathrm{CO}_{2}$ fluxes and may have to be included in the model $[35,74,76]$. Additionally, the exact definition and parameterization of the LUE model may itself affect observations regarding light-use efficiency. Many studies define LUE as the flux rate divided by PAR irradiance (incident PPFD) [71,77], causing the efficiency term to be 
confounded with green canopy structure. In deciduous canopies, this definition of the model terms can lead to large seasonal variations in apparent efficiency that may actually be caused by variations in green canopy structure (the APAR green term of our model), not efficiency as defined in our analysis. As introduced, we defined APAR based on radiation absorbed by green canopies (APAR green), not incident radiation or total absorbed radiation. This distinction and its consequences has been discussed in more detail elsewhere [34]. These differences in model definition and formulation make it difficult to directly compare results across sites and ecosystems, hindering meta-analyses, and confounding larger conclusions beyond the seemingly disparate results of different studies. Consequently, we recommend further attention be given to model formulation with the goal of a standardized definition and parameterization of model terms.

Despite the generally good fit between a simple APAR green-based model and measured $\mathrm{CO}_{2}$ fluxes, some unexplained features remain. In our study, we found that the fit between $\mathrm{CO}_{2}$ fluxes and both NDVI and APAR green presented some hysteresis between the first and second halves of the growing season, a finding that agrees with other recent studies at similar annual-dominated sites [61,78]. Using different equations for these two growth phases considerably improved the flux estimates over the use of a single equation. Such hysteresis could have several causes. It is likely that ecosystem carbon balance between photosynthesis and respiration shifts over the course of the season, contributing to the hysteresis in APAR green and measured fluxes, and this could also cause a seasonal shift in the APAR green-flux patterns that could be interpreted as a change in light-use efficiency [79]. In grasslands, the dead biomass that partially hides new green biomass in the early stage, which is the carry over effect of the previous season's growth, along with the gradually declining chlorophyll and nitrogen content of the leaves during the senescence phase, can also affect the optical-flux relationship. It is possible that our method of partitioning vegetation into "green" and "brown" failed to capture the full dynamics of leaf pigmentation over the season, leading to an apparent change in LUE. Variation in canopy structure (e.g., leaf rolling or leaf inclination angle over the season) could also contribute to this hysteresis. These possibilities warrant further investigation and should be considered in future efforts to model fluxes from optical sensors, particularly if we are to apply the LUE model to all phases of the season. In a similar study, Flanagan et al. [78], documented that $\varepsilon$ could decline in the senescence phase due to low soil moisture and high vapour pressure difference (VPD). Such stress in the late season can explain why a unique equation might not be accurate for modeling seasonal $\mathrm{CO}_{2}$ fluxes. Other studies $[80,81]$ reported that grassland plants quickly respond to changes in moisture conditions and that seasonal patterns of $\varepsilon$ are regulated by water availability [82]. Thus, $\varepsilon$ could decrease from the green-up phase to the maturity phase owing to increasing water stress (and decreasing temperatures) [79]. This finding revealed that environmental stresses that are not related to chlorophyll content or change in structure, cannot always be fully detected using NDVI alone [64]. We conclude that the hypothesis of a constant $\varepsilon$ for our ecosystem seems violated over the entire season (May-October), but holds for half season periods.

Obtaining an adequate optical sampling within the eddy covariance footprint can be a challenging issue $[35,45,83]$. Due to the high variability of the eddy covariance footprint, which varies with wind speed and direction [84], it is not always feasible to directly couple optical and flux footprints, so approximations (e.g., Figure 2) are often necessary. Preliminary results of the flux footprint analysis for our site suggest a typical flux footprint area slightly larger than 1 ha [41]. In our study, the 1 ha grid $\mathrm{NDVI}_{680,800}$ measurements were intended to approximate the footprint of the eddy covariance tower in size, but not necessarily in shape due to the temporal dynamics of the flux footprint. Because $\mathrm{NDVI}_{680,800}$ involved intensive manual sampling, it was limited to periodic measurement and could not provide a sufficiently dense time series to allow close comparison with the continuous flux measurements. Similarly, the spatial coverage of the MODIS NDVI (pixel size nominally $250 \mathrm{~m} \times 250 \mathrm{~m}$ ) provided a reasonable sample of the eddy covariance footprint but could not capture its full temporal dynamics. MODIS NDVI provided a sufficiently frequent time series that (once interpolated to daily data) allowed comparison with seasonal flux measurements. Of the three 
NDVI methods, the proxy NDVI from the automated phenology station provided the most detailed time series, matching the sampling frequency to that of the flux measurements. However, the proxy NDVI footprint was limited to a relatively small area (estimated at a few tens of meters squared), which may have reduced its effectiveness in modeling the $\mathrm{CO}_{2}$ uptake form the much larger and more dynamic flux footprint. These differences in "optical footprint" among NDVI methods undoubtedly influenced our results, presumably contributing to the slight contrasts in seasonal patterns (Figure 5) and the different strengths of correlation between NDVIs and biomass (Figure 6) or net $\mathrm{CO}_{2}$ flux (e.g., Figures 7 and 8). However, a separate analysis of flux footprint assumptions revealed that the errors due to sampling footprint size and shape were much smaller than differences due to site (E3 vs. E5) or season due to the uniform landscape of this site [41]. For other sites with less uniform vegetation stands, the selection of NDVI sampling method and footprint can presumably introduce significant error into the LUE model.

Temporal data aggregation is another important consideration, analogous to the challenge of footprint characterization and matching. Averaging flux and proxy NDVI measurements reduced fine-scale variability of both datasets suggesting that proper temporal aggregation can improve model accuracy when comparing optical and flux data (Table S1, Supplementary Materials). Our findings show that it is crucial to optimize the temporal aggregation when fluxes are related to optical measurements since aggregation can deeply influence the accuracy of the resulting model. For our study, a 5-h averaging period (Table S1) worked well, but we would expect the optimal aggregation period to vary slightly with conditions, e.g., depending upon the stability of the fluxes and optical sampling, which would vary with latitude and daylength across sites. Thus, the topic of optimal aggregation period deserves further study and should be considered as an important issue when predicting fluxes from optical data.

Clearly, one of the challenges of integrating remote and proximal sensing with LUE model in the context of the flux footprint is the need for defining an appropriate temporal and spatial sampling scale. More efforts are needed in the future to further clarify this issue. A detailed investigation of the flux footprint and its dynamics was beyond the scope of this study but was a topic of a separate investigation at this site [41]. While sampling footprint error was low for our site, a possible improvement might derive from integrating a high number of wireless proxy NDVI sensors in order to expand the footprint of optical sampling while maintaining high frequency to better match the footprint and time scale of eddy covariance tower. At our site, we are examining this method of improving the spatial representation of proxy NDVI sampling while preserving the rich time series of automated measurements. More attention should also be given to the potentially confounding effects of spatial or temporal autocorrelation, which were not explicitly considered in our study. In the future, UAVs offer a way to improve the footprint of field optical sampling, but obtaining sufficiently rich time series data will remain a challenge.

The integration of optical and flux measurements can add insights and capabilities beyond those of either measurement alone, in part by using one dataset to inform the other, and by addressing the common problem of missing data. Ongoing integration of optical and flux measurements in the framework of the LUE model offers rich potential for improved evaluation of carbon uptake and sequestration for rangeland sites. Comparisons of optical and flux measurements can provide a basis for extrapolating fluxes beyond the scale of the flux tower footprint to larger areas ("upscaling"), a topic of separate research at our site [41]. Further attention should be given to standardizing these methods across sites and research groups if we are to reach the full potential of integrating optical with flux measurements to deepen our understanding of ecosystem carbon fluxes.

\section{Conclusions}

The main take-home messages of this study exploring the potential of blending different datasets together for monitoring grassland ecosystems are: 
- optical inputs to a simple empirical LUE model closely track seasonal carbon fluxes and provide a simple proxy to fill gaps in the eddy covariance datasets;

- the three NDVI methods give slightly different results depending on different band formulations, footprints and temporal sampling periods; however, low cost sensor (proxy NDVI) can be adopted for monitoring $\mathrm{CO}_{2}$ fluxes;

- proper temporal aggregation improves model accuracy, and further analyses are needed to evaluate the quantitative impact of each aggregation method and period for different sites;

- due to hysteresis and possible stress in the late season, the hypothesis of a constant $\varepsilon$ for our ecosystem seems violated over the entire season (May-October), but holds for half season periods;

- greening and senescence phases of the growing season are best captured using separate model fits and give the most accurate carbon flux estimates (model based on APAR green; $R^{2}=0.69$ for whole season, $R^{2}=0.79$ for green-up phase and $R^{2}=0.77$ for senescence phase);

- this approach is able to distinguish different levels of productivity in the two landscapes sampled, demonstrating the ability to distinguish different levels of carbon uptake.

Supplementary Materials: The following are available online at http://www.mdpi.com/2072-4292/8/3/260/s1, Table S1: $R^{2}$ and equations for fits between net $\mathrm{CO}_{2}$ flux and different midday averaging period of proxy NDVI calculated both for the full season and for the first and second halves (green-up and senescence). The average intervals considered were 5-h, 3-h and 1-h around midday (approximately 13:30 local daylight savings time). In all cases, proxy NDVI was filtered with the method explained in the text.

Acknowledgments: This study was financially supported by grants from the Rangeland Research University (University of Alberta), NSERC, and iCORE/AITF to John A. Gamon. The collaboration between the Italian National Research Council (CNR) and University of Alberta was possible thanks to the COST Action ESO903: "Spectral Sampling Tools for Vegetation Biophysical Parameters and Flux Measurements in Europe" and to the MIUR-CNR Nextdata project. We wish to thank Saulo Castro for field data collection and preliminary data processing, Gilberto Pastorello for assistance in MODIS NDVI products and provision of sensor bandpass data, Adrienne Tastad for information on the vegetation of the sites, Peter Carlson for set up and maintenance of eddy covariance, and Edwin and Ruth Mattheis for providing the University of Alberta with the Mattheis Ranch to support long-term research.

Author Contributions: Enrica Nestola was the primary author and all authors contributed to the final paper. John A. Gamon conceived and designed the experiment. John A. Gamon, Christopher Y.S. Wong and Enrica Nestola collected field data. Enrica Nestola, Craig A. Emmerton, Donnette R. Thayer, Carlo Calfapietra, Christopher Y.S. Wong and John A. Gamon conducted data analysis.

Conflicts of Interest: The authors declare no conflict of interest.

\section{References}

1. Running, S.W. Climate change-Ecosystem disturbance, carbon, and climate. Science 2008, 321, $652-653$. [CrossRef] [PubMed]

2. Fang, C.; Moncrieff, J.B. The dependence of soil $\mathrm{CO}_{2}$ efflux on temperature. Soil Biol. Biochem. 2001, 33, 155-165. [CrossRef]

3. Lynch, D.H.; Cohen, R.D.H.; Fredeen, A.; Patterson, G.; Martin, R.C. Management of Canadian prairie region grazed grasslands: Soil C sequestration, livestock productivity and profitability. Can. J. Soil Sci. 2005, 85, 183-192. [CrossRef]

4. Bonan, G.B. Forests and climate change: Forcings, feedbacks, and the climate benefits of forests. Science 2008, 320, 1444-1449. [CrossRef] [PubMed]

5. Friedel, M.H.; Laycock, W.A.; Bastin, G.N. Assessing rangeland condition and trend. In Field Laboratory Methods for Grassland and Animal Production Research; CABI International: Wallingford, UK, 2000; pp. 227-262.

6. Adams, B.; Ehlert, G.; Stone, C.; Lawrence, D.; Alexander, M.; Willoughby, M.; Hincz, C.; Moisey, D.; Burkinshaw, A.; Carlson, J. Rangeland Health Assessment for Grassland, Forest and Tame Pasture; Rangeland Management Branch, Public Lands \& Forests Division, Alberta Sustainable Resource Development: Edmonton, AB, Canada, 2005. 
7. Allen, V.G.; Batello, C.; Berretta, E.J.; Hodgson, J.; Kothmann, M.; Li, X.; McLvor, J.; Milne, J.; Morris, C.; Peeters, A.; et al. An international terminology for grazing lands and grazing animals. Grass Forage Sci. 2011, 66, 2-28. [CrossRef]

8. Downing, D.J.; Pettapiece, W.W. Natural Regions and Subregions of Alberta; Government of Alberta: Edmonton, AB, Canada, 2006.

9. Adams, B.W.; Poulin-Klein, L.; Moisey, D.; McNeil, R.L. Rangeland Plant Communities and Range Health Assessment Guidelines for the Dry Mixedgrass Natural Subregion of Alberta; Rangeland Management Branch, Public Lands Division, Alberta Sustainable Resource Development: Lethbridge, AB, Canada, 2005.

10. Conant, R.T. Challenges and opportunities for carbon sequestration in grassland systems: A technical report on grassland management and climate change mitigation. In Integrated Crop Management; Food and Agriculture Organization: Rome, Italy, 2010; Volume 9, pp. 1-57.

11. Solomon, A.M.; Prentice, I.C.; Leemans, R.; Cramer, W.P. The interaction of climate and land-use in future terrestrial carbon storage and release. Water Air Soil Pollut. 1993, 70, 595-614. [CrossRef]

12. Wehlage, D.C. Monitoring Year-to-Year Variability in Dry Mixed-Grass Prairie Yield Using Multi-Sensor Remote Sensing. Master's Thesis, University of Alberta, Edmonton, AB, Canada, 2012.

13. Frank, D.A. Drought effects on above- and belowground production of a grazed temperate grassland ecosystem. Oecologia 2007, 152, 131-139. [CrossRef] [PubMed]

14. Hovenden, M.J.; Newton, P.C.D.; Wills, K.E. Seasonal not annual rainfall determines grassland biomass response to carbon dioxide. Nature 2014, 511, 583-586. [CrossRef] [PubMed]

15. Brookshire, E.N.J.; Weaver, T. Long-term decline in grassland productivity driven by increasing dryness. Nat. Commun. 2015, 6. [CrossRef] [PubMed]

16. Stohlgren, T.J.; Bull, K.A.; Otsuki, Y. Comparison of rangeland vegetation sampling techniques in the central grasslands. J. Range Manag. 1998, 51, 164-172. [CrossRef]

17. Lieth, H. Modeling the primary productivity of the world. In Primary Productivity of the Biosphere; Lieth, $\mathrm{H}$., Whittaker, R.H., Eds.; Springer-Verlag: New York, NY, USA; Heidelberg, Germany, 1975; Volume 14, pp. 237-263.

18. Wu, C.; Munger, J.W.; Niu, Z.; Kuang, D. Comparison of multiple models for estimating gross primary production using MODIS and eddy covariance data in Harvard Forest. Remote Sens. Environ. 2010, 114, 2925-2939. [CrossRef]

19. Schimel, D.S.; Braswell, B.H.; Holland, E.A.; McKeown, R.; Ojima, D.S.; Painter, T.H.; Parton, W.J.; Townsend, A.R. Climatic, edaphic, and biotic controls over storage and turnover of carbon in soils. Glob. Biogeochem. Cycles 1994, 8, 279-293. [CrossRef]

20. Ramoelo, A.; Skidmore, A.K.; Schlerf, M.; Heitkonig, I.M.A.; Mathieu, R.; Cho, M.A. Savanna grass nitrogen to phosphorous ratio estimation using field spectroscopy and the potential for estimation with imaging spectroscopy. Int. J. Appl. Earth Obs. Geoinf. 2013, 23, 334-343. [CrossRef]

21. Baldocchi, D.D.; Hicks, B.B.; Meyers, T.P. Measuring biosphere-atmosphere exchanges of biologically related gases with micrometeorological methods. Ecology 1988, 69, 1331-1340. [CrossRef]

22. Valentini, R.; Gamon, J.A.; Field, C.B. Ecosystem gas exchange in a California grassland: Seasonal patterns and implications for scaling. Ecology 1995, 76, 1940-1952. [CrossRef]

23. Soussana, J.F.; Allard, V.; Pilegaard, K.; Ambus, P.; Amman, C.; Campbell, C.; Ceschia, E.; Clifton-Brown, J.; Czobel, S.; Domingues, R.; et al. Full accounting of the greenhouse gas $\left(\mathrm{CO}_{2}, \mathrm{~N}_{2} \mathrm{O}, \mathrm{CH}_{4}\right)$ budget of nine European grassland sites. Agric. Ecosyst. Environ. 2007, 121, 121-134. [CrossRef]

24. Running, S.W.; Nemani, R.R.; Heinsch, F.A.; Zhao, M.S.; Reeves, M.; Hashimoto, H. A continuous satellite-derived measure of global terrestrial primary production. Bioscience 2004, 54, 547-560. [CrossRef]

25. Huemmrich, K.F.; Gamon, J.A.; Tweedie, C.E.; Campbell, P.K.E.; Landis, D.R.; Middleton, E.M. Arctic tundra vegetation functional types based on photosynthetic physiology and optical properties. IEEE J. Sel. Top. Appl. Earth Obs. Remote Sens. 2013, 6, 265-275. [CrossRef]

26. Gamon, J.A.; Rahman, A.F.; Dungan, J.L.; Schildhauer, M.; Huemmrich, K.F. Spectral network (SpecNet)—what is it and why do we need it? Remote Sens. Environ. 2006, 103, 227-235. [CrossRef]

27. Gamon, J.A.; Coburn, C.; Flanagan, L.B.; Huemmrich, K.F.; Kiddle, C.; Sanchez-Azofeifa, G.A.; Thayer, D.R.; Vescovo, L.; Gianelle, D.; Sims, D.A.; et al. SpecNet revisited: Bridging flux and remote sensing communities. Can. J. Remote Sens. 2010, 36, S376-S390. [CrossRef] 
28. Balzarolo, M.; Anderson, K.; Nichol, C.; Rossini, M.; Vescovo, L.; Arriga, N.; Wohlfahrt, G.; Calvet, J.-C.; Carrara, A.; Cerasoli, S.; et al. Ground-based optical measurements at European flux sites: A review of methods, instruments and current controversies. Sensors 2011, 11, 7954-7981. [CrossRef] [PubMed]

29. Monteith, J.L. Solar-radiation and productivity in tropical ecosystems. J. Appl. Ecol. 1972, 9, 747-766. [CrossRef]

30. Monteith, J.L. Climate and efficiency of crop production in Britain. Philos. Trans. R. Soc. B Biol. Sci. 1977, 281, 277-294. [CrossRef]

31. Heinsch, F.A.; Zhao, M.; Running, S.W.; Kimball, J.S.; Nemani, R.R.; Davis, K.J.; Bolstad, P.V.; Cook, B.D.; Desai, A.R.; Ricciuto, D.M.; et al. Evaluation of remote sensing based terrestrial productivity from MODIS using regional tower eddy flux network observations. IEEE Trans. Geosci. Remote Sens. 2006, 44, 1908-1925. [CrossRef]

32. Damm, A.; Guanter, L.; Paul-Limoges, E.; van der Tol, C.; Hueni, A.; Buchmann, N.; Eugster, W.; Ammann, C.; Schaepman, M.E. Far-red sun-induced chlorophyll fluorescence shows ecosystem-specific relationships to gross primary production: An assessment based on observational and modeling approaches. Remote Sens. Environ. 2015, 166, 91-105. [CrossRef]

33. Rossini, M.; Meroni, M.; Migliavacca, M.; Manca, G.; Cogliati, S.; Busetto, L.; Picchi, V.; Cescatti, A.; Seufert, G.; Colombo, R. High resolution field spectroscopy measurements for estimating gross ecosystem production in a rice field. Agric. For. Meteorol. 2010, 150, 1283-1296. [CrossRef]

34. Gitelson, A.A.; Gamon, J.A. The need for a common basis for defining light-use efficiency: Implications for productivity estimation. Remote Sens. Environ. 2015, 156, 196-201. [CrossRef]

35. Gamon, J.A. Reviews and syntheses: Optical sampling of the flux tower footprint. Biogeosciences 2015, 12, 4509-4523. [CrossRef]

36. Lobell, D.B.; Asner, G.P.; Ortiz-Monasterio, J.I.; Benning, T.L. Remote sensing of regional crop production in the Yaqui valley, Mexico: Estimates and uncertainties. Agric. Ecosyst. Environ. 2003, 94, 205-220. [CrossRef]

37. Gamon, J.A.; Field, C.B.; Goulden, M.L.; Griffin, K.L.; Hartley, A.E.; Joel, G.; Penuelas, J.; Valentini, R. Relationships between NDVI, canopy structure, and photosynthesis in three Californian vegetation types. Ecol. Appl. 1995, 5, 28-41. [CrossRef]

38. Hilker, T.; Coops, N.C.; Wulder, M.A.; Black, T.A.; Guy, R.D. The use of remote sensing in light use efficiency based models of gross primary production: A review of current status and future requirements. Sci. Total Environ. 2008, 404, 411-423. [CrossRef] [PubMed]

39. Peñuelas, J.; Garbulsky, M.F.; Filella, I. Photochemical reflectance index (PRI) and remote sensing of plant $\mathrm{CO}_{2}$ uptake. New Phytol. 2011, 191, 596-599. [CrossRef] [PubMed]

40. Myneni, R.B.; Williams, D.L. On the relationship between fAPAR and NDVI. Remote Sens. Environ. 1994, 49, 200-211. [CrossRef]

41. Wang, R.; Gamon, J.A.; Emmerton, C.A.; Li, H.; Nestola, E.; Pastorello, G.Z.; Menzer, O. Integrated analysis of productivity and biodiversity in a southern Alberta prairie. Remote Sens. 2016, 8, 214. [CrossRef]

42. Becker, S. Mattheis Ranch Vegetation and Soil Inventory; Rangelands Research Institute, University of Alberta: Edmonton, AB, USA, 2013.

43. Huemmrich, K.F.; Black, T.A.; Jarvis, P.G.; McCaughey, J.H.; Hall, F.G. High temporal resolution NDVI phenology from micrometeorological radiation sensors. J. Geophys. Res. 1999, 104, 27935-27944. [CrossRef]

44. Nassar, J.M.; Rodríguez, J.P.; Sánchez-Azofeifa, A.; Garvin, T.; Quesada, M. Manual of methods: Human, Ecological and Biophysical Dimensions of Tropical Dry Forests; Instituto Venezolano de Investigaciones Científicas (IVIC): Caracas, Venezuela, 2008.

45. Gamon, J.A.; Cheng, Y.F.; Claudio, H.; MacKinney, L.; Sims, D.A. A mobile tram system for systematic sampling of ecosystem optical properties. Remote Sens. Environ. 2006, 103, 246-254. [CrossRef]

46. Webb, E.K.; Pearman, G.I.; Leuning, R. Correction of flux measurements for density effects due to heat and water-vapor transfer. Q. J. R. Meteorol. Soc. 1980, 106, 85-100. [CrossRef]

47. Moncrieff, J.; Clement, R.; Finnigan, J.; Meyers, T. Averaging, detrending, and filtering of eddy covariance time series. In Handbook of Micrometeorology: A Guide for Surface Flux Measurement and Analysis; Springer Netherlands: Dordrecht, The Netherlands, 2004; Volume 29, pp. 7-31.

48. Ibrom, A.; Dellwik, E.; Flyvbjerg, H.; Jensen, N.O.; Pilegaard, K. Strong low-pass filtering effects on water vapour flux measurements with closed-path eddy correlation systems. Agric. For. Meteorol. 2007, 147, 140-156. [CrossRef] 
49. Wille, C.; Kutzbach, L.; Sachs, T.; Wagner, D.; Pfeiffer, E.-M. Methane emission from Siberian arctic polygonal tundra: Eddy covariance measurements and modeling. Glob. Chang. Biol. 2008, 14, 1395-1408. [CrossRef]

50. Mauder, M.; Foken, T. Impact of post-field data processing on eddy covariance flux estimates and energy balance closure. Meteorol. Z. 2006, 15, 597-609. [CrossRef]

51. Cheng, Y.F.; Gamon, J.A.; Fuentes, D.A.; Mao, Z.Y.; Sims, D.A.; Qiu, H.L.; Claudio, H.; Huete, A.; Rahman, A.F. A multi-scale analysis of dynamic optical signals in a southern California chaparral ecosystem: A comparison of field, AVIRIS and MODIS data. Remote Sens. Environ. 2006, 103, 369-378. [CrossRef]

52. Falge, E.; Baldocchi, D.; Tenhunen, J.; Aubinet, M.; Bakwin, P.; Berbigier, P.; Bernhofer, C.; Burba, G.; Clement, R.; Davis, K.J.; et al. Seasonality of ecosystem respiration and gross primary production as derived from fluxnet measurements. Agric. For. Meteorol. 2002, 113, 53-74. [CrossRef]

53. Moffat, A.M.; Papale, D.; Reichstein, M.; Hollinger, D.Y.; Richardson, A.D.; Barr, A.G.; Beckstein, C.; Braswell, B.H.; Churkina, G.; Desai, A.R.; et al. Comprehensive comparison of gap-filling techniques for eddy covariance net carbon fluxes. Agric. For. Meteorol. 2007, 147, 209-232. [CrossRef]

54. Wohlfahrt, G.; Pilloni, S.; Hoertnagl, L.; Hammerle, A. Estimating carbon dioxide fluxes from temperate mountain grasslands using broad-band vegetation indices. Biogeosciences 2010, 7, 683-694. [CrossRef] [PubMed]

55. Running, S.W. Estimating terrestrial primary productivity by combining remote sensing and ecosystem simulation. In Ecological Studies Analysis and Synthesis; Hobbs, R.J., Mooney, H.A., Eds.; Springer-Verlag New York, Inc.: Secaucus, NJ, USA; Berlin, Germany, 1990; Volume 79, pp. 65-86.

56. Myneni, R.B.; Hall, F.G.; Sellers, P.J.; Marshak, A.L. The interpretation of spectral vegetation indexes. IEEE Trans. Geosci. Remote Sens. 1995, 33, 481-486. [CrossRef]

57. Pettorelli, N.; Vik, J.O.; Mysterud, A.; Gaillard, J.M.; Tucker, C.J.; Stenseth, N.C. Using the satellite-derived NDVI to assess ecological responses to environmental change. Trends Ecol. Evol. 2005, 20, 503-510. [CrossRef] [PubMed]

58. Gamon, J.A.; Huemmrich, K.F.; Stone, R.S.; Tweedie, C.E. Spatial and temporal variation in primary productivity (NDVI) of coastal Alaskan tundra: Decreased vegetation growth following earlier snowmelt. Remote Sens. Environ. 2013, 129, 144-153. [CrossRef]

59. Peng, Y.; Gitelson, A.A.; Keydan, G.; Rundquist, D.C.; Moses, W. Remote estimation of gross primary production in maize and support for a new paradigm based on total crop chlorophyll content. Remote Sens. Environ. 2011, 115, 978-989. [CrossRef]

60. Rossini, M.; Cogliati, S.; Meroni, M.; Migliavacca, M.; Galvagno, M.; Busetto, L.; Cremonese, E.; Julitta, T.; Siniscalco, C.; di Cella, U.M.; et al. Remote sensing-based estimation of gross primary production in a subalpine grassland. Biogeosciences 2012, 9, 2565-2584. [CrossRef]

61. Gitelson, A.A.; Peng, Y.; Arkebauer, T.J.; Schepers, J. Relationships between gross primary production, green LAI, and canopy chlorophyll content in maize: Implications for remote sensing of primary production. Remote Sens. Environ. 2014, 144, 65-72. [CrossRef]

62. Gamon, J.A.; Field, C.B.; Roberts, D.A.; Ustin, S.L.; Valentini, R. Functional patterns in an annual grassland during an aviris overflight. Remote Sens. Environ. 1993, 44, 239-253. [CrossRef]

63. Balzarolo, M.; Vescovo, L.; Hammerle, A.; Gianelle, D.; Papale, D.; Tomelleri, E.; Wohlfahrt, G. On the relationship between ecosystem-scale hyperspectral reflectance and $\mathrm{CO}_{2}$ exchange in European mountain grasslands. Biogeosciences 2015, 12, 3089-3108. [CrossRef]

64. Sakowska, K.; Vescovo, L.; Marcolla, B.; Juszczak, R.; Olejnik, J.; Gianelle, D. Monitoring of carbon dioxide fluxes in a subalpine grassland ecosystem of the Italian Alps using a multispectral sensor. Biogeosciences 2014, 11, 4695-4712. [CrossRef]

65. Field, C.B.; Randerson, J.T.; Malmstrom, C.M. Global net primary production-Combining ecology and remote-sensing. Remote Sens. Environ. 1995, 51, 74-88. [CrossRef]

66. Zhang, Q.; Cheng, Y.-B.; Lyapustin, A.I.; Wang, Y.; Zhang, X.; Suyker, A.; Verma, S.; Shuai, Y.; Middleton, E.M. Estimation of crop gross primary production (GPP): II. Do scaled MODIS vegetation indices improve performance? Agric. For. Meteorol. 2015, 200, 1-8. [CrossRef]

67. Turner, D.P.; Ritts, W.D.; Cohen, W.B.; Maeirsperger, T.K.; Gower, S.T.; Kirschbaum, A.A.; Running, S.W.; Zhao, M.S.; Wofsy, S.C.; Dunn, A.L.; et al. Site-level evaluation of satellite-based global terrestrial gross primary production and net primary production monitoring. Glob. Chang. Biol. 2005, 11, 666-684. [CrossRef] 
68. Turner, D.P.; Ritts, W.D.; Cohen, W.B.; Gower, S.T.; Running, S.W.; Zhao, M.S.; Costa, M.H.; Kirschbaum, A.A.; Ham, J.M.; Saleska, S.R.; et al. Evaluation of MODIS NPP and GPP products across multiple biomes. Remote Sens. Environ. 2006, 102, 282-292. [CrossRef]

69. McCallum, I.; Wagner, W.; Schmullius, C.; Shvidenko, A.; Obersteiner, M.; Fritz, S.; Nilsson, S. Satellite-based terrestrial production efficiency modeling. Carbon Balance Manag. 2009, 4, 8. [CrossRef] [PubMed]

70. Song, C.; Dannenberg, M.P.; Hwang, T. Optical remote sensing of terrestrial ecosystem primary productivity. Prog. Phys. Geogr. 2013, 37, 834-854. [CrossRef]

71. Wu, C.Y.; Niu, Z.; Tang, Q.; Huang, W.J.; Rivard, B.; Feng, J.L. Remote estimation of gross primary production in wheat using chlorophyll-related vegetation indices. Agric. For. Meteorol. 2009, 149, 1015-1021. [CrossRef]

72. Ardö, J. Comparison between remote sensing and a dynamic vegetation model for estimating terrestrial primary production of Africa. Carbon Balance Manag. 2015, 10, 8. [CrossRef] [PubMed]

73. Ruimy, A.; Saugier, B.; Dedieu, G. Methodology for the estimation of terrestrial net primary production from remotely sensed data. J. Geophys. Res. 1994, 99, 5263-5283. [CrossRef]

74. Garbulsky, M.F.; Penuelas, J.; Gamon, J.; Inoue, Y.; Filella, I. The photochemical reflectance index (PRI) and the remote sensing of leaf, canopy and ecosystem radiation use efficiencies a review and meta-analysis. Remote Sens. Environ. 2011, 115, 281-297. [CrossRef]

75. Gitelson, A.A.; Peng, Y.; Masek, J.G.; Rundquist, D.C.; Verma, S.; Suyker, A.; Baker, J.M.; Hatfield, J.L.; Meyers, T. Remote estimation of crop gross primary production with Landsat data. Remote Sens. Environ. 2012, 121, 404-414. [CrossRef]

76. Garbulsky, M.F.; Penuelas, J.; Papale, D.; Ardo, J.; Goulden, M.L.; Kiely, G.; Richardson, A.D.; Rotenberg, E.; Veenendaal, E.M.; Filella, I. Patterns and controls of the variability of radiation use efficiency and primary productivity across terrestrial ecosystems. Glob. Ecol. Biogeogr. 2010, 19, 253-267. [CrossRef]

77. Gilmanov, T.G.; Baker, J.M.; Bernacchi, C.J.; Billesbach, D.P.; Burba, G.G.; Castro, S.; Chen, J.; Eugster, W.; Fischer, M.L.; Gamon, J.A.; et al. Productivity and carbon dioxide exchange of leguminous crops: Estimates from flux tower measurements. Agron. J. 2014, 106, 545-559. [CrossRef]

78. Flanagan, L.B.; Sharp, E.J.; Gamon, J.A. Application of the photosynthetic light-use efficiency model in a northern Great Plains grassland. Remote Sens. Environ. 2015, 168, 239-251. [CrossRef]

79. Nouvellon, Y.; Seen, D.L.; Rambal, S.; Begue, A.; Moran, M.S.; Kerr, Y.; Qi, J.G. Time course of radiation use efficiency in a shortgrass ecosystem: Consequences for remotely sensed estimation of primary production. Remote Sens. Environ. 2000, 71, 43-55. [CrossRef]

80. Bradford, J.B.; Hicke, J.A.; Lauenroth, W.K. The relative importance of light-use efficiency modifications from environmental conditions and cultivation for estimation of large-scale net primary productivity. Remote Sens. Environ. 2005, 96, 246-255. [CrossRef]

81. Yuan, W.; Liu, S.; Zhou, G.; Zhou, G.; Tieszen, L.L.; Baldocchi, D.; Bernhofer, C.; Gholz, H.; Goldstein, A.H.; Goulden, M.L.; et al. Deriving a light use efficiency model from eddy covariance flux data for predicting daily gross primary production across biomes. Agric. For. Meteorol. 2007, 143, 189-207. [CrossRef]

82. Polley, H.W.; Phillips, R.L.; Frank, A.B.; Bradford, J.A.; Sims, P.L.; Morgan, J.A.; Kiniry, J.R. Variability in light-use efficiency for gross primary productivity on great plains grasslands. Ecosystems 2011, 14, 15-27. [CrossRef]

83. Hilker, T.; Nesic, Z.; Coops, N.C.; Lessard, D. A new, automated, multiangular radiometer instrument for tower-based observations of canopy reflectance (AMSPEC II). Instrum. Sci. Technol. 2010, 38, 319-340. [CrossRef]

84. Schmid, H.P. Footprint modeling for vegetation atmosphere exchange studies: A review and perspective. Agric. For. Meteorol. 2002, 113, 159-183. [CrossRef]

(c) 2016 by the authors; licensee MDPI, Basel, Switzerland. This article is an open access article distributed under the terms and conditions of the Creative Commons by Attribution (CC-BY) license (http://creativecommons.org/licenses/by/4.0/). 